\title{
Gallancyra gen. nov. (Phthiraptera: Ischnocera), with an overview of the geographical distribution of chewing lice parasitizing chicken
}

\author{
Daniel R. GUSTAFSSON ${ }^{1, *} \&$ Fasheng ZOU ${ }^{2}$ \\ ${ }^{1}$ Institute of Applied Biological Resources, Xingang West Road 105, Haizhu District, \\ Guangzhou, 510260, Guangdong, China. \\ ${ }^{2}$ Guangdong Key Laboratory of Animal Conservation and Resource Utilization, Guangdong Public \\ Laboratory of Wild Animal Conservation and Utilization, Guangdong, China. \\ ${ }^{*}$ Corresponding author: kotatsu@fripost.org \\ 2Email: zoufs@giabr.gd.cn \\ ${ }^{1}$ urn:1sid:zoobank.org:author:8D918E7D-07D5-49F4-A8D2-85682F00200C \\ ${ }^{2}$ urn:lsid:zoobank.org:author:A0E4F4A7-CF40-4524-AAAE-60D0AD845479
}

\begin{abstract}
The geographical range of the typically host-specific species of chewing lice (Phthiraptera) is often assumed to be similar to that of their hosts. We tested this assumption by reviewing the published records of twelve species of chewing lice parasitizing wild and domestic chicken, one of few bird species that occurs globally. We found that of the twelve species reviewed, eight appear to occur throughout the range of the host. This includes all the species considered to be native to wild chicken, except Oxylipeurus dentatus (Sugimoto, 1934). This species has only been reported from the native range of wild chicken in Southeast Asia and from parts of Central America and the Caribbean, where the host is introduced. Potentially, this discontinuous distribution is due to a low tolerance for dry environments, possibly exacerbated by competitive exclusion by Cuclotogaster heterographus (Nitzsch, 1866). Our examinations of $O$. dentatus also revealed that this species differs significantly from other species of Oxylipeurus in the male and female genitalia, head structure and chaetotaxy, and other morphological characters. We therefore here erect the monotypic genus Gallancyra gen. nov. for O. dentatus, and redescribe the type species.
\end{abstract}

Keywords. Phthiraptera, Oxylipeurus-complex, new genus, biogeography, domestic chicken.

Gustafsson D.R. \& Zou F. 2020. Gallancyra gen. nov. (Phthiraptera: Ischnocera), with an overview of the geographical distribution of chewing lice parasitizing chicken. European Journal of Taxonomy 685: 1-36. https://doi.org/10.5852/ejt.2020.685

\section{Introduction}

The same species of chewing lice are often present throughout the range of a given host. For instance, Adams et al. (2005) found the geographical range of Columbicola columbae (Linnaeus, 1758) to be nearly world-wide, including areas where the host had been introduced. Similarly, Osculonirmus limpidus Mey, 1982, has been found in large parts of its host's range (Gustafsson \& Bush 2017). However, the range of the host and the range of its lice do not always correspond completely. Clay (1976) summarized several examples of chewing louse species that appear to occur only in parts of their hosts' ranges. This 
includes several cases where different congeneric species of chewing lice occur in different parts of the host's range; further examples of this type of pattern have subsequently been published for many other host species (e.g., Johnson et al. 2002; Malenke et al. 2011; Gustafsson \& Bush 2017).

The causes for local or regional absence of a species of chewing louse on a host are typically not known. In cases where the range of the host has expanded, either naturally or by human intervention, cases of "missing the boat" (Paterson \& Gray 1997) may be common. This term describes the chance event that not all parasite species were present on the specific individuals that colonized a new area, and formed the basis for the range extension. For instance, not all louse species found in the hosts' native range have been found on introduced species in North America (Boyd 1951; Brown \& Wilson 1975) and New Zealand (Paterson et al. 1999); though in some cases, the perceived absence of a louse species in an area may be due to insufficient sampling (e.g., Galloway \& Palma 2008).

However, "missing the boat" events may be impossible to distinguish from local extinction after an introduction event ("drowning on arrival"; Paterson et al. 1999). Paterson et al. (1999) predicted that 1-2 chewing louse species would normally be lost per introduction event. Intuitively, instances of "missing the boat" should decrease with increasing numbers of introduction events, especially when introduction events may originate from different source populations. Unless there is some bias in either which species of chewing lice are present on the source population or which species of chewing lice survive the introduction event, these losses should be compensated for if multiple introduction events are involved.

Such biases may include the impact of the external environment on the population structure of chewing lice on a given host. For instance, Moyer et al. (2002) showed that low ambient humidity decreased both the number of lice on bird and the number of birds that were infested with lice. Ambient humidity has since been demonstrated to have an effect on chewing louse distribution also in wild birds (Bush et al. 2009; Malenke et al. 2011). Notably, Bush et al. (2009) showed that ambient humidity may affect different louse species differently.

Data on the presence of chewing lice on birds is normally patchy, and the true geographical range of most louse species is unknown. Most described species of chewing lice have been collected only once or a few times, often from the same region, and very few hosts have been sampled extensively for lice throughout the range of the host.

The domestic chicken, Gallus gallus (Linnaeus, 1758), is among the most widely distributed bird species in the world, occurring almost everywhere there are humans. Due to the economic importance of chicken, numerous surveys of infectious and parasitic diseases of chicken have been conducted, collectively covering almost all faunal regions where chicken occur (e.g., Table 1). As a result, domestic chicken has among the best-known louse faunas of any bird species. In total, 22 species of chewing lice are known from domestic chicken across the world (Table 2).

We here summarize the known distribution of several species of chewing lice with a focus on Lipeurus dentatus Sugimoto, 1934, hitherto placed in the genus Oxylipeurus Mjöberg, 1910 (Price et al. 2003). This species is rarely reported in the literature (Table 1), and was not included in a recent overview of the chewing lice of chicken (Khan et al. 2016). We redescribe and reillustrate this species here, and erect a new genus, Gallancyra gen. nov., based on significant morphological differences between this species and all other species of the Oxylipeurus-complex. We also summarize the geographical distribution of eleven other chewing louse species occurring on domestic and wild chicken, based on published records. We hope this redescription and overview will enable veterinarians and louse researchers to identify $G$. dentata gen. et comb. nov. in future surveys. This may shed some light over the discontinuous geographical distribution of this species, and over the development of differences in geographical distribution between different species of chewing lice parasitizing the same host. 
Table 1 (continued on next three pages). Summary of the geographical distribution of Gallancyra dentata (Sugimoto, 1934) gen. et comb. nov. The following published reports and checklists were consulted to establish the geographical range of twelve species of chewing lice parasitizing domestic and wild chicken. Kéler (1939) summarized the known distribution of the goniodid species at the time, and we here refer to his summary for brevity. Slides deposited at the NHMUK but not previously published are referred to with their slide identification number (NHMUKXXXXXXXXX) and '(NHMUK)'. Locality data for specimens marked 'This study' can be found under the redescription of $G$. dentata gen. et comb. nov.

\begin{tabular}{|c|c|c|}
\hline Region and country & $\begin{array}{c}\text { Gallancyra dentata } \\
\text { present }\end{array}$ & Source \\
\hline \multicolumn{3}{|r|}{ Afrotropical } \\
\hline "Africa" & No & Emerson (1956) \\
\hline Algeria & No & Kéler (1939); Ilyes et al. (2013); Meguini et al. (2018) \\
\hline Benin & No & Love et al. (2017) \\
\hline Egypt & No & Hafez \& Madbouly (1966); El-Aw et al. (2008) \\
\hline Ethiopia & No & $\begin{array}{l}\text { Emerson (1956); Ashenafi \& Yimer (2005); Belihu et al. } \\
\text { (2009); Tolossa et al. (2009); Mekuria \& Gezahegn (2010); } \\
\text { Amede et al. (2011); Tolossa \& Tafesse (2013); Tamiru } \\
\text { et al. (2014); Alemu et al. (2015); Zeryuhan \& Yohannes } \\
\text { (2015); Kebede et al. (2017); Mata et al. (2018); Serda \& } \\
\text { Abdi (2018) }\end{array}$ \\
\hline Ghana & No & Aboagye et al. (2014) \\
\hline Kenya & No & Emerson (1956); Mungube et al. (2008) \\
\hline Liberia & No & Peters (1931); Clay (1940); Emerson (1956) \\
\hline Libya & No & Gabaj et al. (1993); Mansur et al. (2019) \\
\hline Malawi & No & Banda (2011) \\
\hline Nigeria & No & $\begin{array}{l}\text { Clay (1940); Adene \& Dipeolu (1975); Fabiyi (1980, } \\
\text { 1986, 1996); Okaeme (1988); George et al. (1992); Zaria } \\
\text { et al. (1996); Sadiq et al. (2003); Ikpeze et al. (2008); } \\
\text { Natala et al. (2009); Ekpo et al. (2010); Bala et al. (2011); } \\
\text { Edusomwan et al. (2011); Usman et al. (2012); Odenu } \\
\text { et al. (2016); Lawal et al. (2016, 2017); Emmanuel et al. } \\
\text { (2017); Bassey \& Marroh (2018); Edusomwan \& Igetei } \\
\text { (2018); Ahaotu et al. (2019) }\end{array}$ \\
\hline Saudi Arabia & No & Aldryhim (1991); Gharsan \& Elhassan (2019) \\
\hline South Africa & No & $\begin{array}{l}\text { Bedford (1924); Kéler (1939); Mukaratirwa \& Khumalo } \\
\text { (2012); Moyo et al. (2015) }\end{array}$ \\
\hline Sudan & No & Kéler (1939) \\
\hline Tanzania & No & Swai et al. (2010) \\
\hline Tunisia & No & Kaboudi et al. (2019) \\
\hline Uganda & No & Clay (1940) \\
\hline Zimbabwe & No & $\begin{array}{l}\text { Permin et al. (2002); Mukaratirwa \& Hove (2009); Percy } \\
\text { et al. (2012) }\end{array}$ \\
\hline \multicolumn{3}{|r|}{ Indo-Malayan } \\
\hline Bangladesh & No & Shanta et al. (2006) \\
\hline Cambodia & No & Segal et al. $(1968)^{\mathrm{a}}$ \\
\hline
\end{tabular}


Table 1 (continued). Summary of the geographical distribution of Gallancyra dentata (Sugimoto, 1934) gen. et comb. nov.

\begin{tabular}{|c|c|c|}
\hline Region and country & $\begin{array}{c}\text { Gallancyra dentata } \\
\text { present }\end{array}$ & Source \\
\hline \multirow[t]{2}{*}{ India } & No & $\begin{array}{l}\text { Kéler (1939); Clay (1940); Ansari (1946); Emerson } \\
\text { (1956); Chopra (1968); Trivedi et al. (1991, 1992); Lonc } \\
\text { et al. (1992); Saxena et al. (2004); Salam et al. (2009); } \\
\text { Bhat et al. (2014); Mishra et al. (2016a, 2016b) }\end{array}$ \\
\hline & Yes & This study \\
\hline Indonesia & No & Kéler (1939); Clay (1940) \\
\hline \multirow[t]{2}{*}{ Laos } & No & Emerson \& Elbel (1957a) \\
\hline & Yes & Segal et al. (1968) \\
\hline \multirow[t]{2}{*}{ Malaysia } & No & $\begin{array}{l}\text { Amin-Babjee et al. (1997); Rahman \& Haziqah (2015); } \\
\text { Suhaila et al. (2015) }\end{array}$ \\
\hline & Yes & This study \\
\hline Myanmar & No & Clay (1940) \\
\hline Philippines & Yes & $\begin{array}{l}\text { Emerson \& Elbel (1957a); Manuel \& Anceno (1981); } \\
\text { Portugaliza \& Bagot (2015) }\end{array}$ \\
\hline "Southeast Asia" & No & Emerson (1956) \\
\hline Sri Lanka & No & Clay (1940) \\
\hline Taiwan & Yes & Sugimoto $(1930,1934)$ \\
\hline Thailand & Yes & $\begin{array}{l}\text { Clay (1940); Emerson \& Elbel (1957a); Segal et al. } \\
\text { (1968); NHMUK010682397 (NHMUK) }\end{array}$ \\
\hline Vietnam & No & Clay (1940); Segal et al. (1968) \\
\hline \multicolumn{3}{|r|}{ Nearctic } \\
\hline Canada & No & $\begin{array}{l}\text { Kéler (1939); Clay (1940); Emerson (1956); Thompson \& } \\
\text { Hosking (1957); Thompson (1968) }\end{array}$ \\
\hline "North America" & No & Emerson (1956) \\
\hline USA & No & $\begin{array}{l}\text { Kéler (1939); MacCreary \& Catts (1954); Emerson } \\
\text { (1956); Murillo \& Mullens (2016) }\end{array}$ \\
\hline \multicolumn{3}{|r|}{ Neotropic } \\
\hline Argentina & No & Kéler (1939); Ferrero et al. (2004) \\
\hline Bahamas & No & Peters (1931); Kéler (1939) \\
\hline Brazil & No & $\begin{array}{l}\text { Emerson (1956); Figueiredo et al. (1993); Oliveira et al. } \\
\text { (1999); Santos-Prezoto et al. (2003); Guerra et al. (2008); } \\
\text { Santos et al. (2011) }\end{array}$ \\
\hline "British West Indies" & No & Emerson (1956) \\
\hline "Central America" & No & Emerson (1956) \\
\hline Chile & No & González-Acuña et al. (2009) \\
\hline Colombia & No & Marín-Gómez \& Benavides-Montaño (2007) \\
\hline Costa Rica & Yes & Hernandez-Divers et al. (2008) \\
\hline Cuba & Yes & De Zayas (1941); Emerson (1956); Černy (1969) \\
\hline Ecuador & No & Hernandez-Divers et al. (2006) \\
\hline Guyana & No & Clay (1940) \\
\hline
\end{tabular}


Table 1 (continued). Summary of the geographical distribution of Gallancyra dentata (Sugimoto, 1934) gen. et comb. nov.

\begin{tabular}{|c|c|c|}
\hline Region and country & $\begin{array}{c}\text { Gallancyra dentata } \\
\text { present }\end{array}$ & Source \\
\hline Mexico & No & $\begin{array}{l}\text { Clay (1940); Cruz et al. (2013); Sánchez-Montes et al. } \\
\text { (2018) }\end{array}$ \\
\hline Nicaragua & Yes & Emerson $(1956)$ \\
\hline Panama & Yes & Peters (1935); Emerson (1956) \\
\hline \multirow[t]{2}{*}{ Puerto Rico } & No & $\begin{array}{l}\text { Emerson (1956); Maldonado-Cipriles \& Miro-Mercado } \\
\text { (1978) }\end{array}$ \\
\hline & Yes & NHMUK010682387 (NHMUK) \\
\hline Venezuela & No & $\begin{array}{l}\text { Peters (1931); Emerson (1956); Martínez de Chirinos } \\
\text { et al. (2001) }\end{array}$ \\
\hline \multicolumn{3}{|r|}{ Oceania } \\
\hline Australia & No & Emerson (1956); Palma \& Baker (1996) \\
\hline New Guinea & Yes & This study \\
\hline New Zealand & No & Palma (2017) \\
\hline $\begin{array}{l}\text { "Various islands in } \\
\text { Central Pacific Area" }\end{array}$ & Yes & Emerson (1956) \\
\hline \multicolumn{3}{|r|}{ Palearctic } \\
\hline Bulgaria & No & Preiesov (1998); Prelezov \& Koinarski (2006) \\
\hline China & No & $\begin{array}{l}\text { Emerson (1957); Liu (1985); Arnold (2008); Wang et al. } \\
\text { (2010) }\end{array}$ \\
\hline Czech Republic & No & Sychra et al. (2008) \\
\hline "Europe" & No & Emerson (1956) \\
\hline Finland & No & Backlund (1934); Kéler (1939); Hackman (1994) \\
\hline France & No & Séguy (1944) \\
\hline Germany & No & Kéler (1939); Mey (2003) \\
\hline Holland & No & Kéler (1939) \\
\hline Hungary & No & Kéler (1939) \\
\hline Iran & No & $\begin{array}{l}\text { Rafyi et al. (1968); Vazirianzadeh et al. (2007); Eslami } \\
\text { et al. (2009); Rezaei et al. (2016); Mirzaei et al. (2016) }\end{array}$ \\
\hline Iraq & No & $\begin{array}{l}\text { Aliraqi \& Amin (2007); Abdullah \& Mohammed (2013); } \\
\text { Thamer et al. (2016); Al-Shaibani et al. (2018) }\end{array}$ \\
\hline Japan & No & Kéler (1939); Matsudaira \& Kaneko (1969) \\
\hline Kazakhstan & No & Blagoveshtchensky (1940) \\
\hline Pakistan & No & $\begin{array}{l}\text { Buriro \& Akbar (1978); Shahjehan \& Iqbal (1995); } \\
\text { Naheed \& Adna (2004); Nadeem et al. (2007); Naz et al. } \\
\text { (2016) }\end{array}$ \\
\hline Poland & No & Kéler (1939); Lonc et al. (1992) \\
\hline Romania & No & Clay (1940); Pisica (1985); Morariu et al. (2008) \\
\hline Russia & No & Blagoveshtchensky (1940) \\
\hline South Korea & No & Noh et al. (1989) \\
\hline Spain & No & Martin-Mateo et al. (1980) \\
\hline
\end{tabular}


Table 1 (continued). Summary of the geographical distribution of Gallancyra dentata (Sugimoto, 1934) gen. et comb. nov.

\begin{tabular}{lcl}
\hline Region and country & $\begin{array}{c}\text { Gallancyra dentata } \\
\text { present }\end{array}$ & \multicolumn{1}{c}{ Source } \\
\hline Sweden & No & $\begin{array}{l}\text { Kéler (1939); Jansson et al. (2004); Gustafsson } \text { et al. } \\
(2019)\end{array}$ \\
\hline Tajikistan & No & Blagoveshtchensky (1940, 1951) \\
Turkey & No & $\begin{array}{l}\text { Mimioglu (1952); Dik et al. (1999); Köroglu et al. (1999); } \\
\text { Aldemir (2004); Sayin Ipek \& Saki (2009); Orunç \& }\end{array}$ \\
& Biçek (2009); Inci et al. (2010); Döner \& Yaman (2015) \\
\hline Ukraine & No & Blagoveshtchensky (1940); Yevstafieva (2015) \\
\hline United Kingdom & No & Kéler (1939); Clay (1940); Ryder (1967) \\
\hline
\end{tabular}

a Segal et al. (1968) also report "Lipeurus heteroglyphus" from several localities. No such species has ever been described, and it is unclear whether this refers to Cuclotogaster heterographus, Lipeurus tropicalis, or some other species. We have omitted these records in Fig. 2.

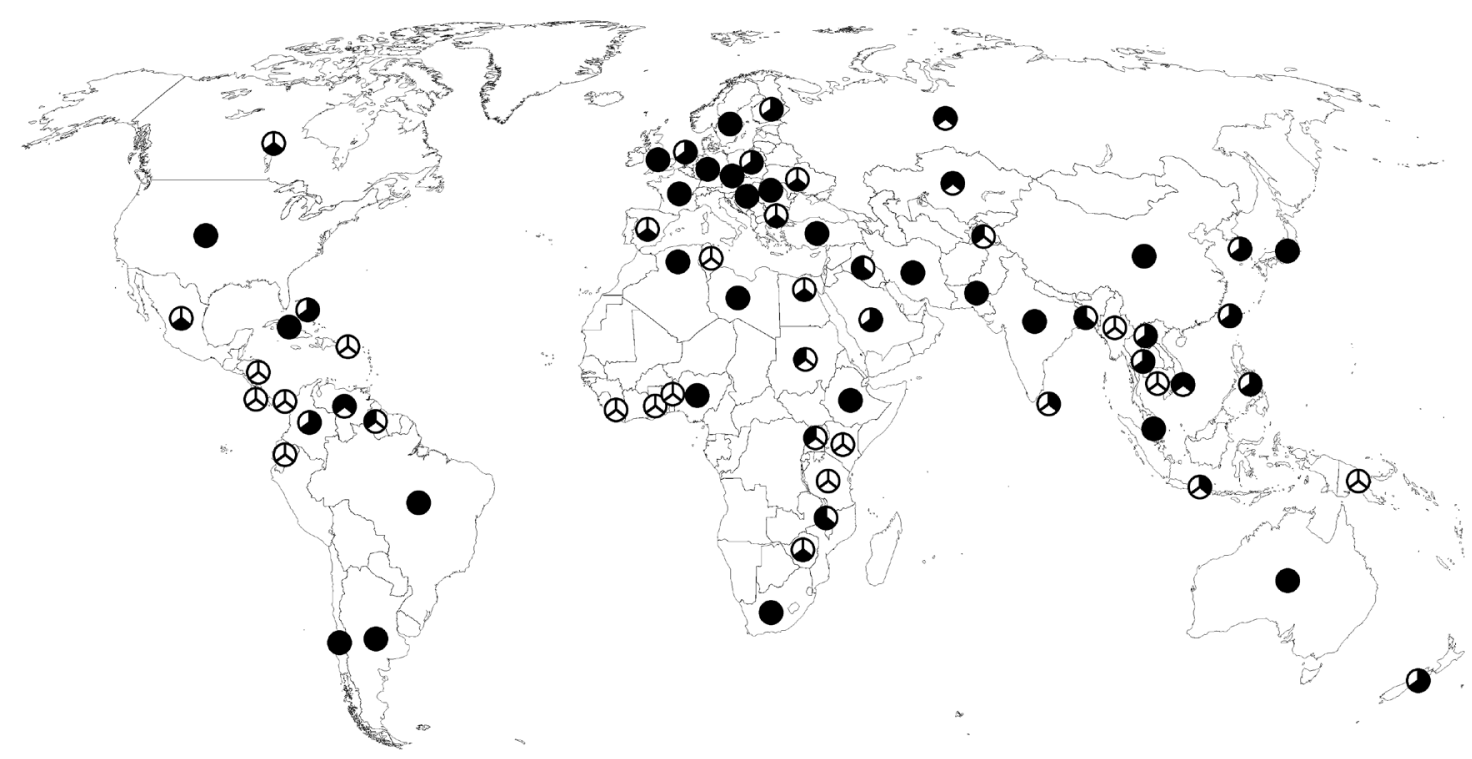

Fig. 1. Geographical distribution of three species of ischnoceran chewing lice parasitizing wild and domestic chicken (Gallus spp). Each circle is divided into three sectors, representing the three louse species: upper left $=$ Goniodes gigas $($ Taschenberg, 1879); upper right $=$ Goniodes dissimilis Denny, 1842 ; lower $=$ Goniocotes gallinae (De Geer, 1778). Black sectors indicate that this louse species is known from this country, whereas hollow sectors indicate that we have found no published records of this species in this country. Presence of the three species of chewing lice in a country is based on the reports summarized in Table 1. 
Table 2 (continued on next page). Species of chewing lice reported from domestic chicken. Data sources are Emerson (1956) and Price et al. (2003), unless otherwise stated. Note that this list contains fewer species than that provided by Khan et al. (2016). This discrepancy is due to Khan et al. (2016) listing synonyms as separate species, and including reports of lice collected from domestic pigeons. Moreover, some species listed by Khan et al. (2016) are not reported in the sources they cite; these species have been excluded here.

\begin{tabular}{|c|c|}
\hline Chewing louse species & Notes and sources \\
\hline \multicolumn{2}{|c|}{ Amblycera } \\
\hline Amyrsidea powelli (Bedford, 1920) & Fabiyi $(1986,1996)^{\mathrm{a}}$ \\
\hline Amyrsidea saudiensis Alahmed et al., 2017 & $\begin{array}{l}\text { Alahmed et al. (2017); presently known } \\
\text { only from Saudi Arabia }{ }^{\text {b }}\end{array}$ \\
\hline Colpocephalum turbinatum Denny, 1842 & Oliveira et al. (1999) ${ }^{\mathrm{c}}$ \\
\hline \multicolumn{2}{|l|}{ Menacanthus cornutus (Schömmer, 1913) } \\
\hline Menacanthus longiscleritus Naz \& Rizvi, 2016 & $\begin{array}{l}\text { Naz \& Rizvi (2016); presently known only } \\
\text { from Pakistan }\end{array}$ \\
\hline Menacanthus numidae (Giebel, 1874) & $\begin{array}{l}\text { Séguy (1944); Martín-Mateo }(1973,1974 a \text {, } \\
\text { 1974b); Martín-Mateo et al. }(1980)^{\mathrm{e}}\end{array}$ \\
\hline \multicolumn{2}{|l|}{ Menacanthus pallidulus (Neumann, 1912) } \\
\hline \multicolumn{2}{|l|}{ Menacanthus stramineus (Nitzsch, 1818) } \\
\hline Menopon gallinae (Linnaeus, 1758) & f \\
\hline \multicolumn{2}{|c|}{ Ischnocera } \\
\hline Campanulotes compar (Burmeister, 1838) & Ferreira et al. $(2013)^{g}$ \\
\hline Chelopistes meleagridis (Linnaeus, 1758) & $\begin{array}{l}\text { Martínez de Chirinos et al. (2001); Meguini } \\
\text { et al. }(2018)^{\mathrm{h}}\end{array}$ \\
\hline Cuclotogaster heterographus (Nitzsch, 1866) & i \\
\hline Cuclotogaster occidentalis (Tendeiro, 1954) & Fabiyi $(1986,1996)^{\mathrm{j}}$ \\
\hline \multicolumn{2}{|l|}{ Gallancyra dentata (Sugimoto, 1934) } \\
\hline \multicolumn{2}{|l|}{ Goniocotes gallinae (De Geer, 1778) } \\
\hline Goniocotes maculatus (Taschenberg, 1882) & $\mathrm{k}$ \\
\hline Goniocotes microthorax (Stephens, 1829) & Sychra et al. $(2008)^{1}$ \\
\hline Goniodes dispar Burmeister, 1838 & Blagoveshtchensky $(1951)^{\mathrm{m}}$ \\
\hline \multicolumn{2}{|l|}{ Goniodes dissimilis Denny, 1842} \\
\hline Goniodes gigas (Taschenberg, 1879) & ${ }^{n}$ \\
\hline \multicolumn{2}{|l|}{ Lagopoecus sinensis (Sugimoto, 1930) } \\
\hline Lipeurus caponis (Linnaeus, 1758) & o \\
\hline Lipeurus tropicalis Peters, 1931 & $\mathrm{p}$ \\
\hline
\end{tabular}

a The natural host of $A$. powelli is Numida meleagris (Linnaeus, 1758), and these lice may be established on domestic chicken only locally.

${ }^{\text {b }}$ First reported by Aldryhim (1991), and may represent a straggler from another bird. Specimens of the same species were also found on Coturnix coturnix (Linnaeus, 1758), but the species is apparently morphologically different from the Amyrsidea species normally found on that host.

c The natural host for C. turbinatum is Columba livia Gmelin, 1789. Oilveira et al. (1999) suggested that chicken may be an occasional natural host of $C$. turbinatum, as there was no risk of contamination during their examination. We know of no other reports of C. turbinatum on chicken. Martínez de Chirinos et al. (2001) reported 
Table 2 (continued). Species of chewing lice reported from domestic chicken.

Colpocephalum sp. from chicken, which presumably is also C. turbinatum. This host switch is likely due to hosts living in close proximity, but it is possible that C. turbinatum has secondarily established locally on domestic chicken.

${ }^{d}$ It is not clear from the original description how this species differs from other species of Menacanthus from the same host, as most stated differences appear to be in measurements. Measurements of both M. longiscleritus and the other species of the genus found on the same host are given without ranges. It is therefore not possible to establish whether the differences in dimensions are due to the small sample size. The only useful morphological character stated to be diagnostic is the length of the genital sclerite, which is twice as long in M. longiscleritus as in any of the other species of Menacanthus occurring on chicken. It is not clear whether this is sufficient to merit status as a separate species, but we tentatively accept it as valid here. It is known only from two males and one nymph collected in Pakistan. The natural host of this species may thus be some other species. Notably, sclerites of similar length are found in some species of Menacanthus from passeriform hosts (Price 1977), but no comparison with species parasitizing passeriform hosts were included in the original description.

e The natural host of M. numidae is Numida meleagris, and records from domestic chicken likely originate from stragglers among birds in mixed poultry flocks.

${ }_{\mathrm{f}}^{\mathrm{E}}$ Emerson \& Elbel (1957b) reported this species from Lophura diardi (Bonaparte, 1856).

g Almost certainly stragglers, as the natural host of C. compar is Columba livia Gmelin, 1789.

h The natural host of C. meleagridis is Meleagris gallopavo Linnaeus, 1758, and reports of this species from domestic chicken likely originate from stragglers among birds in mixed poultry flocks.

i Emerson (1956) noted that this species has never been collected from wild chicken, and that the natural host is most likely some species of partridge in the genus Alectoris Kaup, 1829. It has recently been recorded from domestic turkey, indicating that it is capable to dispersing to new hosts (Dik et al. 2015).

j The natural host of Cuclotogaster occidentalis is Pternistis bicalcarata (Linnaeus, 1766) (Tendeiro 1958). Fabiyi (1986) found it on both domestic chicken and Numida meleagris.

k The natural host of G. maculatus is Numida meleagris, but it was originally described from domestic chicken. The only subsequent records of G. maculatus on domestic chicken appears to be Müller (1927) and Blagoveshchensky (1951); however, it is not clear from these publications how it was established that these lice were not G. gallinae. We include this species here for completeness.

1 The natural hosts of Goniodes microthorax are Perdix perdix (Linnaeus, 1758) and Alectoris chukar (Gray, 1830). Sychra et al. (2008) found this species only on chickens that were reared in a pheasant farm, and presumed this record to be the result of straggling.

m Goniodes dispar are normally found on hosts in the genera Alectoris Kaup, 1829, and Perdix Linnaeus, 1758. Blagoveshtchensky's records may derive from misidentifications or stragglers, but may also represent a local population established on domestic chicken in Tajikistan. To our knowledge, this is the only report of G. dispar on domestic chicken.

${ }^{\mathrm{n}}$ Emerson (1956) believed that Goniodes gigas originated from some species of guineafowl, as the same species is known from this host group.

- Reports of this species from peacock (e.g., Marniche et al. 2017) may represent either misidentifications, stragglers, or local host switches, and do not suggest that this is the natural host of $L$. caponis.

${ }^{\mathrm{p}}$ Lipeurus tropicalis is also known from Numida meleagris (e.g., Clay 1938; Emerson 1956). Its closest relative, Lipeurus lawrensis Bedford, 1929, occurs exclusively on guineafowl, which suggested to Emerson (1956) that some species of guineafowl may be the natural host of $L$. tropicalis, and that this species has subsequently spread throughout chicken populations across the world. 


\section{Material and methods}

All examined specimens were previously slide-mounted in Canada balsam and deposited at the Natural History Museum, London, United Kingdom (NHMUK). Specimens were examined in an Eclipse Ni (Nikon Corp., Tokyo, Japan) microscope fitted with a drawing tube. Illustrations were made by hand, scanned, and edited in GIMP (www.gimp.org). Measurements were made from live images in Evos FL Auto (Thermo Fischer Scientific, Hong Kong, China), comprising the following dimensions (all in millimeters): $\mathrm{AW}=$ abdominal width (at posterior end of segment $\mathrm{V}$ ); $\mathrm{HL}=$ head length (at midline); $\mathrm{HW}=$ head width (at temples); PRW = prothoracic width; PTW = pterothoracic width; TL = total length (at midline). Terminology for morphological and setal characters (and their abbreviations) follows Gustafsson \& Bush (2017): $a 2=$ anterior seta 2; $a d s=$ anterior dorsal seta; pmes = posterior mesosomal seta; $p s t 1-2=$ parameral setae $1-2 ; v m s=$ vulval marginal seta; $v s s=$ vulval submarginal seta. All setae mentioned in the text are marked in the figures. Host taxonomy follows Clements et al. (2019).

To assess the geographical range of $G$. dentata gen. et comb. nov. and other lice known from domestic chicken, we performed an extensive literature review. Searches were made primarily in Google Scholar (scholar.google.com) and on the louse literature database in Phthiraptera.info, using each of the louse species known from domestic chicken as search terms, in isolation or in combination with the search terms 'domestic chicken', 'poultry', and 'hen'. We also contacted our international network of colleagues and, in some cases, corresponding authors of publications we could not find. No attempt was made to find all published literature from before 1934, the year Lipeurus dentatus was described, as these are unlikely to contain identifiable references to this species. Ultimately, it is possible that not all published records could be obtained, as they were not caught in our searches. This applies particularly to reports in older journals or smaller veterinary journals that do not have digitized summaries, content lists, or abstracts, and to reports in languages other than English that do not include the scientific names of the

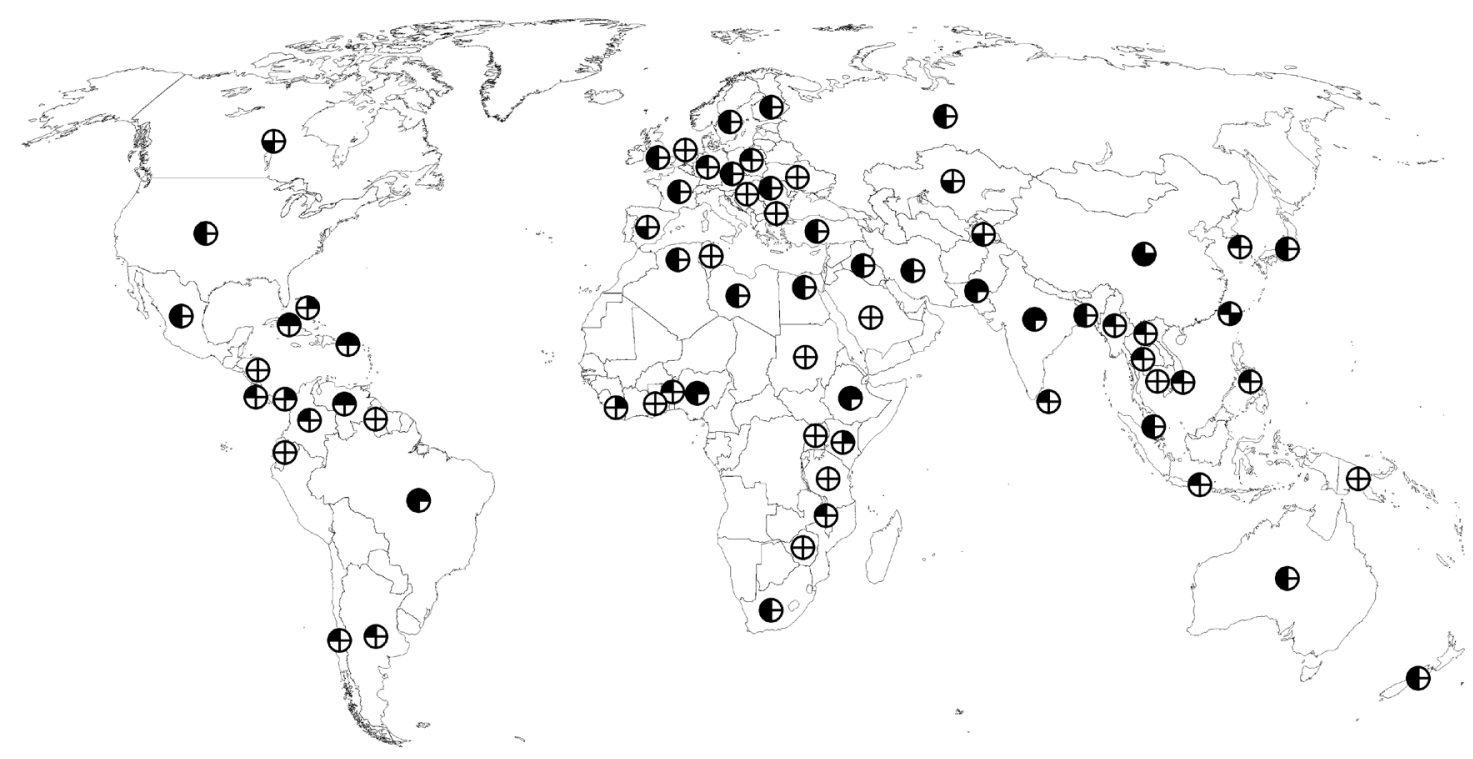

Fig. 2. Geographical distribution of four species of ischnoceran chewing lice parasitizing wild and domestic chicken (Gallus spp.). Each circle is divided into four sectors, representing the four louse species: upper left = Lipeurus caponis (Linnaeus, 1758); upper right =Lipeurus tropicalis Peters, 1931; lower left =Cuclotogaster heterographus (Nitzsch, 1866); lower right = Lagopoecus sinensis (Sugimoto, 1930). Black sectors indicate that this louse species is known from this country, whereas hollow sectors indicate that we have found no published records of this species in this country. Presence of the four species of chewing lice in a country is based on the reports summarized in Table 1. 
lice we searched for. Reports published in conference proceedings or outside the scientific literature have also not been searched comprehensively.

\section{Results}

The known geographical distributions of eight species of ischnoceran chewing lice and four species of amblyceran chewing lice known from domestic chicken are summarized in Figs 1-4, based on the sources listed in Table 1. Note that these maps do not include species such as Chelopistes meleagridis (Linnaeus, 1758) (Meguini et al. 2018) or Goniocotes microthorax (Stephens, 1829) (Sychra et al. 2008) that represent stragglers originating from mixed poultry flocks. Cases where the lice appear to have been erroneously identified to genus or species level (e.g., Sadiq et al. 2003) are also not included.

Comparisons between specimens of Oxylipeurus dentatus and other lice in the genus Oxylipeurus indicate that this species is morphologically distinct, and very different from other species in the Oxylipeuruscomplex. We here describe a new genus for this species, Gallancyra gen. nov.

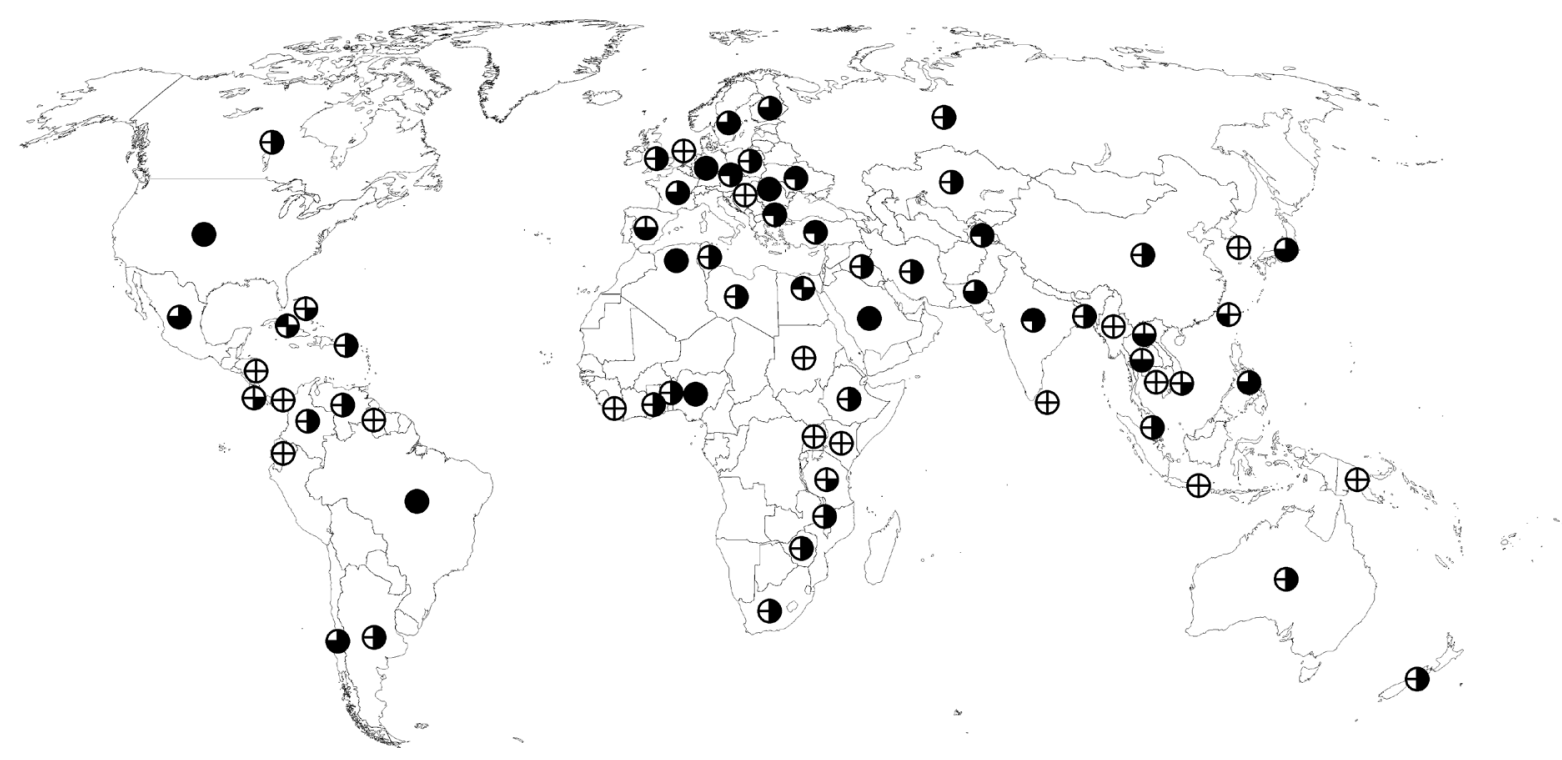

Fig. 3. Geographical distribution of four species of menoponid chewing lice parasitizing wild and domestic chicken (Gallus spp.). Each circle is divided into four sectors, representing the four louse species: upper left $=$ Menacanthus cornutus (Schömmer, 1913); upper right = Menacanthus stramineus (Nitzsch, 1818); lower left = Menacanthus pallidulus (Neumann, 1912); lower right = Menopon gallinae (Linnaeus, 1758). Black sectors indicate that this louse species is known from this country, whereas hollow sectors indicate that we have found no published records of this species in this country. The presence of the four species of chewing lice in a country is based on the reports summarized in Table 1. Note that the menoponid species Amyrsidea powelli (Bedford, 1920) appears to be established on chicken in Nigeria (Fabiyi 1986, 1996), and that Menacanthus longiscleritus Naz \& Rizvi, 2016, has been described from chicken in Pakistan. These are not shown on the map. 


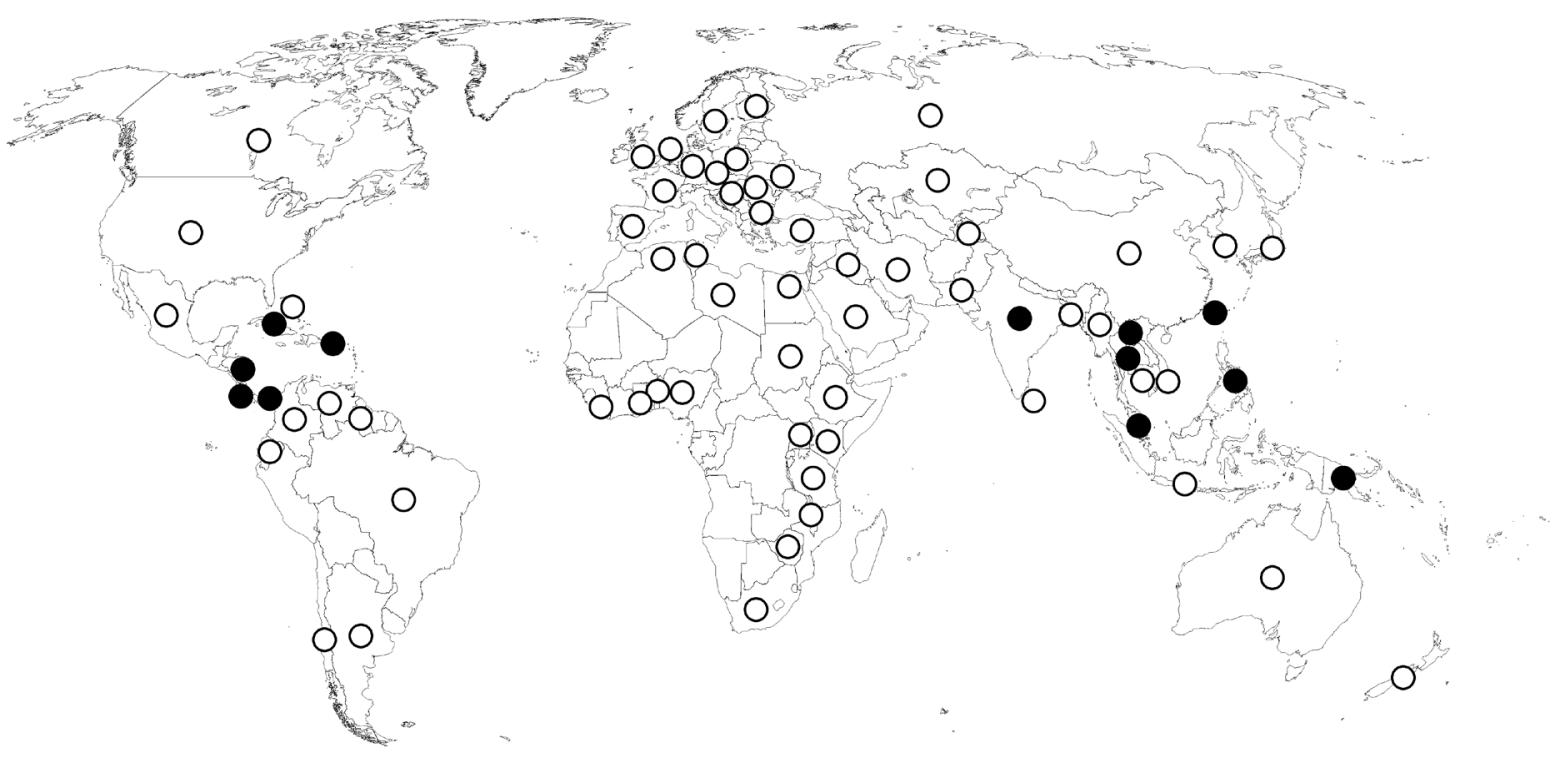

Fig. 4. Geographical distribution of the known records of Gallancyra dentata (Sugimoto, 1934), based on the reports cited in Table 1. Black circles indicate countries where G. dentata has been reported at in at least one survey, including the present report. Hollow circles indicate countries for which surveys of domestic chicken have been published, but $G$. dentata has not been found. In addition to the areas indicated on the map, Emerson (1956) reported G. dentata from "various islands in the Central Pacific Area”, but gave no detail.

Order Phthiraptera Haeckel, 1896

Suborder Ischnocera Kellogg, 1896

Family Philopteridae Burmeister, 1838

Oxylipeurus-complex

Genus Gallancyra Gustafsson \& Zou gen. nov. urn:1sid:zoobank.org:act:7C0E09CF-B1F7-4A97-81E5-74DF2C0CD4C6

Figs 5-14

Lipeurus Nitzsch, 1818: 292 (in partim).

Oxylipeurus Mjöberg, 1910: 91 (in partim).

Reticulipeurus Kéler, 1958: 332 (in partim).

\section{Type species}

Lipeurus dentatus Sugimoto, 1934.

\section{Diagnosis}

Lipeurus dentatus was previously placed either in Oxylipeurus (e.g., Price et al. 2003) or in Reticulipeurus (e.g., Mey 2003). Of these two genera, Gallancyra is most similar to Reticulipeurus (see, e.g., Kéler (1958) and Gustafsson et al. (2020) for illustrations of most of these characters in Reticulipeurus, and Mey (1990) for corresponding characters in Oxylipeurus s. str.; see also Table 3), with which it shares the following characters: stylus extends beyond distal margin of abdomen (Fig. 7); intertergal plates absent (Figs 5-6); mesosome large, with hook-shaped antero-lateral corners, rugose distal margins, and ventral gonopore associated with transverse sclerite which bears setae laterally (Fig. 13); parameres 
symmetrical, at most about twice as long as mesosome, and roughly finger-shaped (Fig. 12); female subgenital plate much reduced, typically divided medially (Fig. 8); vulval opening converging medially to single, typically narrow, point, not forming convex lobes laterally (Fig. 12); post-antennal suture absent (Fig. 9).

\section{Etymology}

Gallancyra is constructed from the Latin name 'gallus', for 'chicken' and the genus of the type host of the type species, and the Greek word 'ancyra', for 'anchor'. This refers to the shape of the stylus of the male subgenital plate. The gender is feminine.

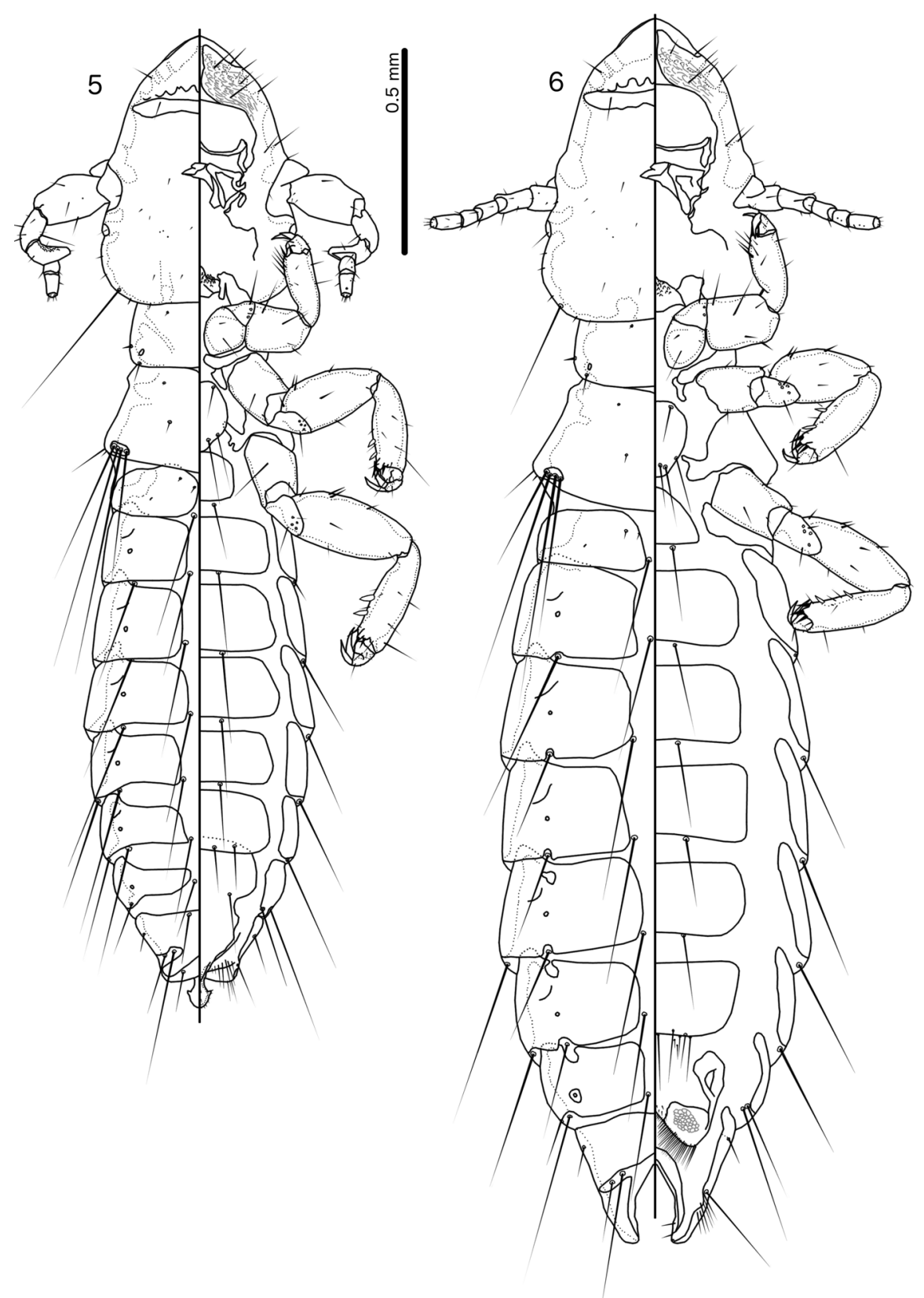

Figs 5-6. Gallancyra dentata (Sugimoto, 1934) gen. et comb. nov. ex Gallus gallus (Linnaeus, 1758) (NHMUK010682393). 5. Habitus, $\hat{\partial}$, dorsal and ventral view. 6. Habitus, + , dorsal and ventral views. Legs II and III distorted in all examined males, here illustrated approximately, and rotated compared to how they are in the slide specimen. 


\section{Differential diagnosis}

Gallancyra gen. nov. can be separated from Reticulipeurus by the following characters: preantennal head pointed in Gallancyra gen. nov. (Fig. 9), but rounded in Reticulipeurus; preantennal head in Gallancyra gen. nov. ventrally with clypeo-labral suture that divides sclerotized section of ventral head into two lobes, and that expands in anterior end, seemingly making ventral side of frons hyaline (Fig. 9), but without any clypeo-labral suture and with no ventral hyaline region in Reticulipeurus; tergopleurites with clear reticulation at least laterally on some segments in Reticulipeurus, but without clear reticulation in Gallancyra gen. nov. (Figs 5-6); stylus arising from distal margin and with protruding section expanded into anchor-shape in Gallancyra gen. nov. (Fig. 7), but arising subterminally and with protruding section not or only little expanded, and never anchor-shaped in Reticulipeurus; rugose section of distal mesosome

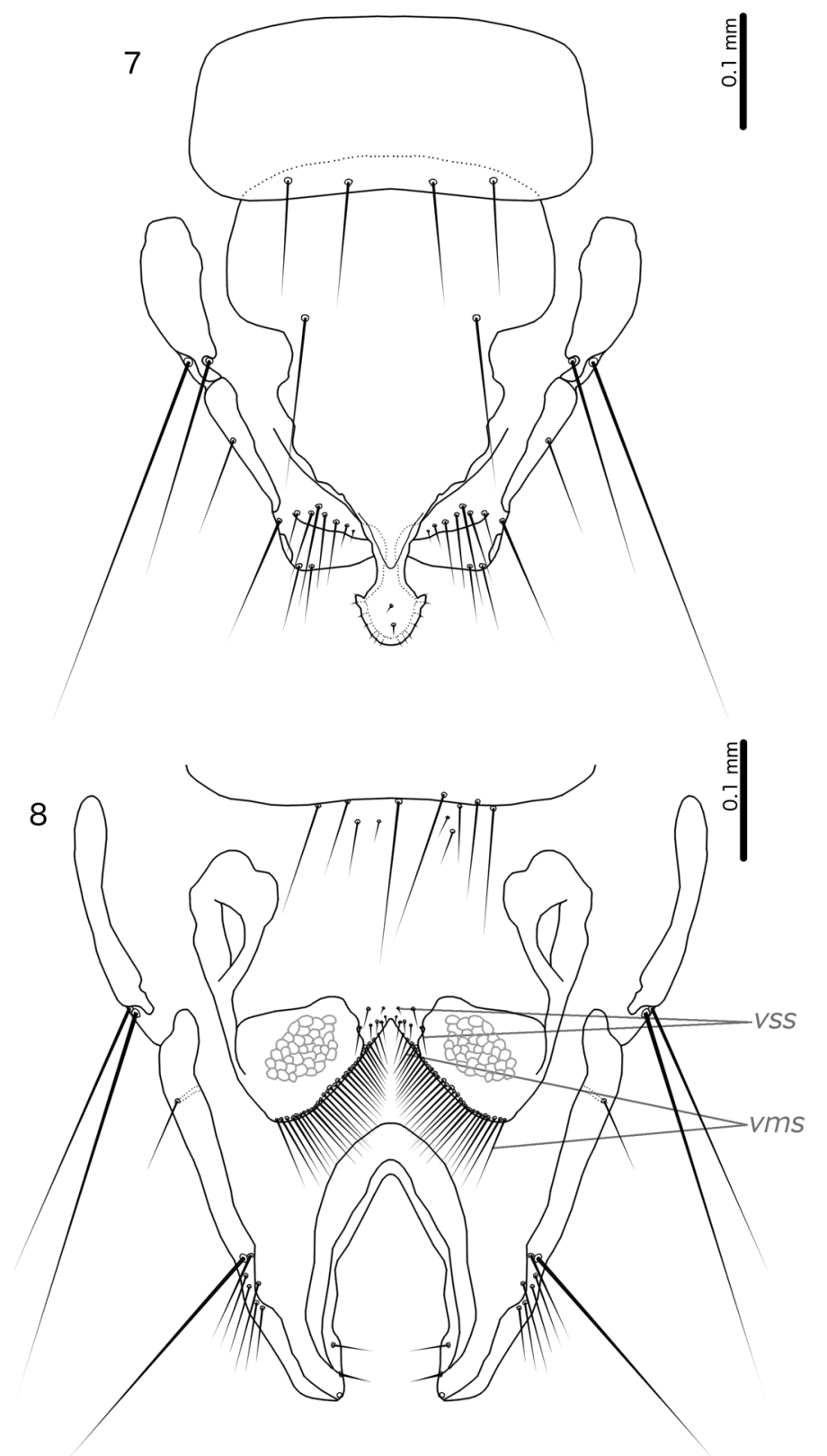

Figs 7-8. Gallancyra dentata (Sugimoto, 1934) gen. et comb. nov. ex Gallus gallus (Linnaeus, 1758) (NHMUK010682393). 7. Male subgenital plate and terminal end of abdomen, ventral view. 8. Female subgenital plate and terminal end of abdomen, ventral view. Abbreviations: vms = vulval marginal setae; vss $=$ vulval submarginal setae. 
limited to lateral margins and expanding medially in anterior end in Gallancyra gen. nov. (Fig. 13), but typically limited to distal margin and not expanded in anterior end in Reticulipeurus; sclerotized plate present on distal mesosome in Gallancyra gen. nov. (Fig. 13), but absent in Reticulipeurus; pst1-2 placed close-together subterminally, and both with visible microsetae in Gallancyra gen. nov. (Fig. 12), but $p s t 1$ is a sensillus and typically placed well proximal of pst 2 in Reticulipeurus; subvulval sclerites present in Reticulipeurus, but absent in Gallancyra gen. nov. (Fig. 8).

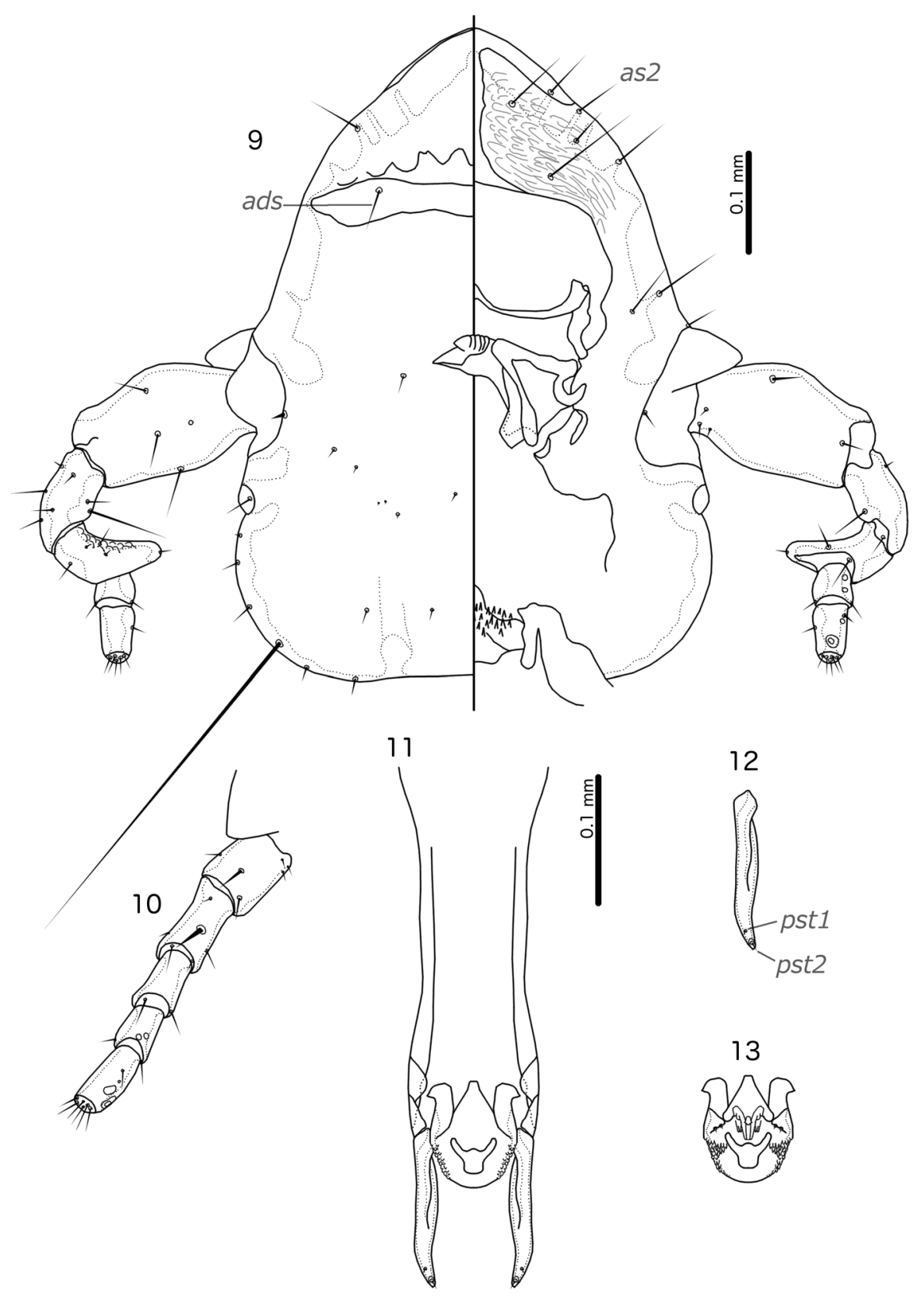

Figs 9-13. Gallancyra dentata (Sugimoto, 1934) gen. et comb. nov. ex Gallus gallus (Linnaeus, 1758) (NHMUK010682393). 9. Male head, dorsal and ventral views. 10. Female antenna, ventral view. 11. Male genitalia, dorsal view. 12. Male paramere, dorsal view. 13. Male mesosome, ventral view. Female antenna at same scale as male head. Abbreviations: $a d s=$ anterior dorsal seta; $a s 2=$ anterior seta $2 ;$ st $1-2=$ parameral setae 1-2. All genitalic component drawn at same scale. 
Table 3. Morphological comparison of Gallancyra gen. nov., Reticulipeurus Kéler, 1958 and Oxylipeurus Mjöberg, 1910. Note that genitalia of Oxylipeurus s. str. are hard to homologize with those of other genera in the complex based on published illustrations (e.g., Mey 1990). In particular, the mesosome of species in this genus appears to be much reduced and fused to the basal apodeme.

\begin{tabular}{|c|c|c|c|}
\hline Characters & Gallancyra gen. nov. & $\begin{array}{l}\text { Reticulipeurus } \\
\text { Kéler, } 1958\end{array}$ & $\begin{array}{l}\text { Oxylipeurus s. str. } \\
\text { Mjöberg, } 1910\end{array}$ \\
\hline Frons & Pointed & Rounded & Pointed or rounded \\
\hline Hyaline margin & Prominent ventrally & Absent & Absent \\
\hline Ventral carina & Medianly interrupted & Medianly continuous & Medianly continuous \\
\hline Post-antennal suture & Absent & Absent & Present \\
\hline $\begin{array}{l}\text { Reticulation of } \\
\text { tergopleurites }\end{array}$ & Absent & $\begin{array}{l}\text { Present but variable in } \\
\text { extent }\end{array}$ & Absent \\
\hline Intertergal plates & Absent & Absent & Present \\
\hline Stylus position & Arising terminally & Arising subterminally & Arising terminally \\
\hline Stylus length & $\begin{array}{l}\text { Reaching beyond distal } \\
\text { margin of abdomen }\end{array}$ & $\begin{array}{l}\text { Reaching beyond distal } \\
\text { margin of abdomen }\end{array}$ & $\begin{array}{l}\text { Not reaching distal } \\
\text { margin of abdomen }\end{array}$ \\
\hline Stylus shape & Anchor-shaped & $\begin{array}{l}\text { More or less equal in } \\
\text { width throughout }\end{array}$ & Short and blunt \\
\hline Female subgenital plate & $\begin{array}{l}\text { Much reduced, divided } \\
\text { medianly }\end{array}$ & $\begin{array}{l}\text { Much reduced, divided } \\
\text { or continuous medianly }\end{array}$ & $\begin{array}{l}\text { Not reduced, medianly } \\
\text { continuous }\end{array}$ \\
\hline Vulval margin & Without lateral lobes & Without lateral lobes & With lateral lobes \\
\hline Subvulval plates & Absent & Present & Unknown? ${ }^{1}$ \\
\hline Mesosome & $\begin{array}{l}\text { Large, anterior ends } \\
\text { hook-shaped }\end{array}$ & $\begin{array}{l}\text { Large, anterior ends } \\
\text { hook-shaped }\end{array}$ & $\begin{array}{l}\text { Much reduced, may be } \\
\text { absent }\end{array}$ \\
\hline Rugose areas & Mainly lateral & $\begin{array}{l}\text { Across all or most of } \\
\text { distal margin }\end{array}$ & Absent \\
\hline $\begin{array}{l}\text { Distal sclerotized plate of } \\
\text { mesosome }\end{array}$ & Present & Absent & Absent \\
\hline Gonopore & $\begin{array}{l}\text { With transverse sclerite } \\
\text { bearing setae }\end{array}$ & $\begin{array}{l}\text { With transverse sclerite } \\
\text { bearing setae }\end{array}$ & Much reduced \\
\hline Parameres & $\begin{array}{l}\text { Symmetrical, roughly } \\
\text { finger-shaped }\end{array}$ & $\begin{array}{l}\text { Symmetrical, roughly } \\
\text { finger-shaped }\end{array}$ & $\begin{array}{l}\text { Asymmetrical, roughly } \\
\text { triangular }\end{array}$ \\
\hline pst1-2 & $\begin{array}{l}\text { Close together } \\
\text { subterminally, both } \\
\text { microsetae }\end{array}$ & $\begin{array}{l}\text { Separated, pst1 } \\
\text { typically sensillus }\end{array}$ & Unknown? ${ }^{1}$ \\
\hline
\end{tabular}

1 This character is not clearly visible in the illustrations of Mey (1990), and we have not examined any specimens belonging to any species of Oxylipeurus s. str. 
The structure of the preantennal head (Fig. 9) and the stylus (Fig. 7) of Gallancyra dentata gen. et comb. nov. are unique within the Oxylipeurus-complex and, to the extent of our knowledge, the entire Ischnocera. These two characters should separate Gallancyra gen. nov. from all other genera of ischnoceran chewing lice.

\section{Description}

\section{Both sexes}

Head overall trapezoidal, widening posteriorly, but with frons triangularly extended into medial point (Fig. 9). Hyaline margin seemingly present as very narrow translucent band near frons; this is not visible in all examined specimens, and in many cases differs between sides of the same specimen. Marginal carina uninterrupted, but displaced dorsally anterior to as2; most preantennal setae with clear attendant canals going through the marginal carina. Internal thickenings present anterior to ads, varying in extent among specimens. Dorsal preantennal suture present, enveloping aperture of ads, and approaching but not reaching lateral margins of head. Ventrally, head capsule appears to be hyaline medially and anteriorly, with sclerotized sections densely decorated with semi-reticulated pattern. Ventral carina not clearly visible. Head and antennal chaetotaxy as in Fig. 9. Preantennal nodi large, bulging. Antennae sexually dimorphic (Figs 9-10). Pre-and postocular nodi present. Occipital carinae not visible. Temporal carinae visible only in posterior section, connecting to bulbous nodi. Gular plate diffuse, approximately as in Fig. 9; area around gular plate with conspicuous spiculate thickenings.

Thoracic segments and chaetotaxy as in Figs 5-6. Pronotum and pteronotum each medially continuous. Meso- and metanota fused into single plate. Metepisterna broad, medial end with finger-like extension that may reach pteronotum. Legs and leg chaetotaxy as in Fig. 14; anterior setae of trochanters II-III may be present, but not visible in examined species as legs are distorted. At least two setae on medial margin of tibiae II-III appear to be hyaline and larger than other setae (illustrated as hollow). Abdominal segments and chaetotaxy as in Figs 5-6. Tergopleurites II-VIII medially divided, tergopleurite IX+X medially continuous. Internal thickening of antero-lateral corners of tergopleurites present on segments III-VII. Sternal plates present on segments II-VII.

\section{Male}

Antennae as in Fig. 9; scape, pedicel, and flagellomere I expanded compared to female; flagellomere I with thumb-like extension and rugose medial surface. Subgenital plate seemingly protruding internally to sternal plate VII (Fig. 7). Stylus arises from distal margin of subgenital plate and reaches beyond distal margin of abdomen; distal section of stylus expanded, with lateral margins extended into small "hooks" in anterior end. Basal apodeme slender, lateral margins slightly concave, anterior end diffuse (Fig. 11). Mesosome with antero-lateral sclerotized hook-shaped extensions, distally with rounded margin and rugose area only laterally (Fig. 13). Gonoporal complex small compared to mesosome. Sclerotized plate with arched antero-lateral extensions. Parameres as in Fig. 12; pst 1-2 both microsetae.

\section{Female}

Antennae as in Fig. 10. Distal end of abdomen as in Fig. 8. Subgenital plate divided medially, with conspicuous honey-comb reticulation in central parts. Vulval margin deeply concave. Most distal anal seta apparently modified to sensilla, as only alveoli are visible in examined specimens.

\section{Host distribution}

Presently only known from hosts in the genus Gallus Brisson, 1760. This genus is closely related to the genus Bambusicola Gould, 1836 (Armstrong et al. 2001; Dyke et al. 2003; Kimball \& Braun 2008; Wang et al. 2013), but no species of the Oxylipeurus-complex lice are known from hosts in the genus Bambusicola. 


\section{Geographical range}

See Table 1 and Fig. 4; primarily the Indo-Malayan region and Central America, but also known from New Guinea, the Caribbean, and islands in the Central Pacific. Seemingly absent over large parts of the host's (introduced) range, but may be overlooked.

\section{Remarks}

Złotorzycka (1966) considered the species here placed in Gallancyra gen. nov. to belong in Oxylipeurus s. str., but did not justify this placement other than by reference to published illustrations. Presumably her judgement was based on the presence of an anteriorly pointed head in both Gallancyra dentata gen. et comb. nov. and species of Oxylipeurus, whereas other genera in the complex generally have rounded preantennal heads. Comparing G. dentata gen. et comb. nov. to more recent illustrations of Oxylipeurus s. str. (e.g., Mey 1990) shows that, apart from the pointed head, there are few morphological similarities between the two genera. For instance, Oxylipeurus s. str. has intertergal plates, medially continuous tergopleurites VII-VIII, a post-antennal suture, much reduced and highly modified male genitalia, and a small, distally blunt, stylus.
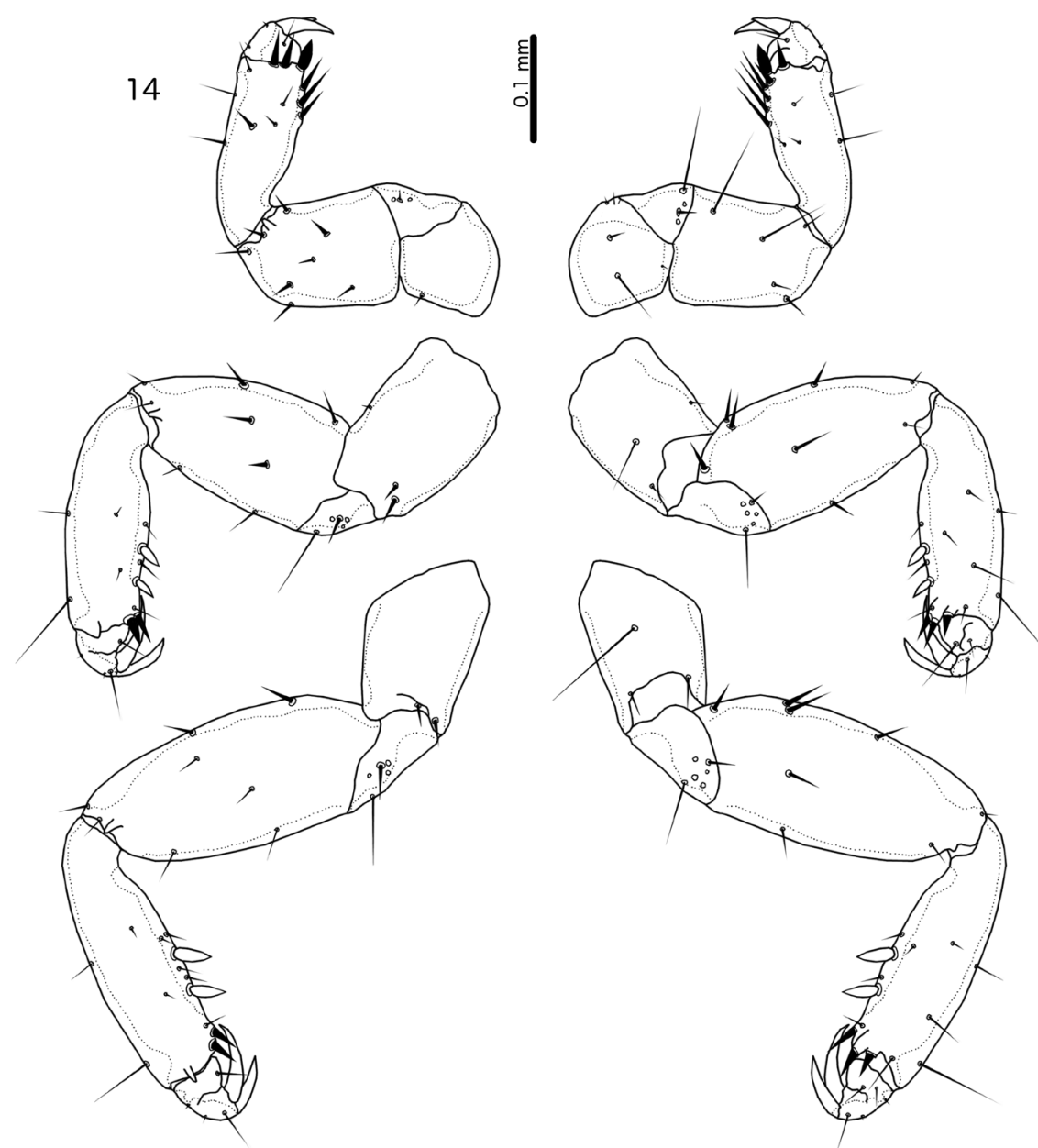

Fig. 14. Gallancyra dentata (Sugimoto, 1934) gen. et comb. nov. ex Gallus gallus (Linnaeus, 1758) (NHMUK010682393). Male legs I-III, dorsal and ventral views. Legs II and III distorted in all examined males, and here illustrated approximately; note that marginal and near-marginal setae (marked with small black circles) are illustrated on both dorsal and ventral side, as their exact placement is difficult to establish due to the distortion of the legs. Some setae on tibiae II-III appear hyaline in examined specimens, and have here been illustrated as hollow. 
Gallancyra dentata (Sugimoto, 1934) gen. et comb. nov.

Lipeurus dentatus Sugimoto, 1934: 2, figs 1-11 +2 unnumbered photos.

Lipeurus angularis Peters, 1935: 101, figs 1-3.

Oxylipeurus dentatus - Clay, 1938: 181.

Reticulipeurus dentatus (Sugimoto, 1935) [sic] - Mey 2003: 90.

\section{Type host}

Gallus gallus (Linnaeus, 1758) - Red Junglefowl (domestic chicken).

\section{Other hosts}

Gallus gallus murghi Robinsson \& Kloss, 1920; Gallus gallus spadiceus (Bonnaterre, 1790) (Emerson \& Elbel 1956: 382); Gallus lafayettii Lesson, 1831 (Price et al. 2003: 203) - Sri Lanka Junglefowl. "[S]everal of the wild chickens of Southeast Asia" (Emerson 1956: 78).

\section{Type locality}

Taiwan.

\section{Material examined}

\section{Non-type material}

Ex Gallus gallus murghi

INDIA • 1 ภ, 2 우; Sikkim; Jan. 1922; R. Meinertzhagen, 345; NHMUK010682390; NHMUK.

Ex Gallus gallus ssp.

PAPUA NEW GUINEA • 2 q 9 ; Central District, Kapogere Area; Apr. 1971; I.L. Owen leg.; 1192/71; Brit.Mus. 1971-292; NHMUK010682394; NHMUK.

MALAYSIA • 1 क; Trengganu; 1968; A. Mustaffa leg.; Brit. Mus. 1968-292; NHMUK010682389 - 2 ふึે, 3 우; Trengganu; Jun. 1969; A. Mustaffa leg.; Brit. Mus. 1969-396; NHMUK010682393; NHMUK.

\section{Description}

\section{Both sexes}

See genus description; below are listed only details of those characters typically variable among species in the Oxylipeurus-complex.

\section{Male}

Proximal mesosome extended into rather trapezoidal structure that overlaps with distal section of basal apodeme (Fig. 13); this section is rather diffuse in specimens, and has here been illustrated approximately. Antero-lateral sections of mesosome elongated hook-shaped, more intensely sclerotized than trapezoidal section. Distal mesosome gently rounded, with rugose areas limited to lateral margins; rugose section expands medially in anterior end. Sclerotized plate present in central part of distal mesosome, with arched antero-lateral extensions on each side. Gonopore slender, not reaching distal half of mesosome. A single tube situated on each side of gonopore, which may terminate in sensilla, but no such sensillae visible in examined specimens. Two pmes microsetae visible on each side lateral to gonopore. Parameres slender, without distinct head; $p s t 1-2$ as in Fig. 12, both subterminal microsetae. Measurements $(\mathrm{n}=3$, except TL and PTW where $\mathrm{n}=2$ ); $\mathrm{TL}=2.22-2.32 ; \mathrm{HL}=0.63-064 ; \mathrm{HW}=0.44-0.46 ; \mathrm{PRW}=0.32-0.35$; $\mathrm{PTW}=0.44-0.46 ; \mathrm{AW}=0.53-0.62$. 


\section{Female}

Vulval margin with 20-32 vms on each side, and 11-15 vss gathered in the central section. In both sets of setae, lateral setae are longer than medial setae. Measurements $(\mathrm{n}=8) ; \mathrm{TL}=2.54-2.84 ; \mathrm{HL}=0.70-0.74$; $\mathrm{HW}=0.51-0.55 ; \mathrm{PRW}=0.36-0.42 ; \mathrm{PTW}=0.52-0.59 ; \mathrm{AW}=0.69-0.75$.

\section{Remarks}

Peters (1935), Clay (1938), Emerson (1956) and Price et al. (2003) all list "Lipeurus denticlypeus Sugimoto, 1934" as a synonym or potential synonym of $O$. dentatus. Clay (1938: 181) noted that the change in name is only in the reprint, not in the published version of the manuscript. As such, it has never been published, and is at best considered a manuscript name, with no nomenclatorial existence.

Moreover, the translation of this manuscript is usually given as "On a new species of Mallophaga, Lipeurus denticlypeatus n. sp., from the Formosan fowl" (e.g., Price et al. 2003). The original Japanese title does not include either the name of the louse, the name of the host, or the origin of the specimens. It roughly translates to "Additional information on the head lice of domestic birds". No information on the location on Sugimoto's type specimens appears to be included in the original description, and the location of the holotype is unknown. As we have no evidence that it has been destroyed or lost, we here do not select a neotype for $L$. dentatus.

A single examined male of $G$. dentata gen. et comb. nov. from Gallus gallus murghi has a larger head with a blunter preantennal area than males from G. g. gallus, but heads of females from the two host subspecies are near identical. Other characters are largely indistinguishable between specimens from the two host subspecies, but the male genitalia of the single male from G. g. murghi are destroyed and partially obscured by gut content, and cannot be compared adequately. As so few specimens have been examined from either host subspecies, and the natural variation is thus not known, we presently do not consider these differences to be significant, until a large series of specimens have been examined. We therefore consider specimens from both host subspecies to be conspecific.

\section{Discussion}

The extensive introductions of domestic chicken into almost all parts of the world make this species an ideal model for examining the effect of the external environment on the parasite fauna of a bird. Moreover, the economic importance of domestic chicken has led to many surveys of their ectoparasite fauna (Table 1), in contrast to the often very limited geographical data known for lice on most wild birds. We have summarized the known geographical ranges of all species of chewing lice occurring on domestic chicken (Figs 1-4; Table 1). Below, we discuss these ranges and the possible limitations to them, for each species of chewing louse known from domestic chicken.

\section{Chewing lice presumably native to chicken}

Emerson (1956) considered only six chewing louse species (Goniocotes gallinae (De Geer, 1778), Goniodes dissimilis Denny, 1842, Lipeurus caponis (Linnaeus, 1758), Menacanthus pallidulus (Neumann, 1912), Menopon gallinae (Linnaeus, 1758), Gallancyra dentata gen. et comb. nov.) as definitely having chicken as their natural host, based on records from non-domesticated hosts in Southeast Asia. A seventh species, Menacanthus cornutus (Schömmer, 1913), he considered doubtful, as he had only examined a single specimen from a wild chicken from Southeast Asia. This species has also been recorded from turkey (Camacho-Escobar et al. 2014).

Of the six louse species Emerson (1956) presumed to be native to chicken, four (G. gallinae, G. dissimilis, L. caponis and M. gallinae) appear to be near global in their distribution (Figs 1-3), with no obvious gaps in their distribution that cannot be explained by the patchiness of sampling efforts. All four species 
appear to occur in both drier and more humid habitats, and in both colder and warmer areas. However, Fabiyi (1996) reported that G. dissimilis and M. gallinae are absent in areas with short humid season, perhaps mirroring the environmental conditions in the native range of chicken. In the same study, L. caponis and G. gallinae showed no preference for areas with either short or long humid season. Trivedi et al. (1992) stated that the highest prevalence of $L$. caponis was during periods with slightly lower temperatures, whereas the other four species increased during periods of higher temperature.

Menacanthus pallidulus is reported less often than the others in surveys. Fabiyi (1996) reported that this species is absent in areas with a shorter humid season, which may explain its absence in some areas. However, M. pallidulus does not seem to be common on the host. Do Carmo Rezende et al. (2016) found M. pallidulus in only $3.7 \%$ of the examined chickens, a prevalence less than half that of M. cornutus and M. stramineus (Nitzsch, 1818) in the same study. Similarly, only 30 of almost 25000 lice collected from chicken by Ilyes et al. (2013) were identified as M. pallidulus. However, the records shown in Fig. 3 span most of the range of domestic chicken. It is absent in most of Sub-Saharan Africa, but this may be an artifact of sampling, as it is present in Nigeria, the country with the highest number of surveys (Table 1). More data are needed before the true range of M. pallidulus can be approximated.

By contrast, Gallancyra dentata gen. et comb. nov. has a very limited distribution (Fig. 4), which is split between the native range of chicken (Southeast Asia), New Guinea and Central Pacific Islands (Emerson 1956) as well as parts of Central America and the Caribbean. All these areas are tropical and Hohorst (1939) listed G. dentata gen. et comb. nov. under "Tropical species".

Gallancyra dentata gen. et comb. nov. is rarely reported in the literature. In a recent review of louse infestation in domestic chicken, the species was not even included (Khan et al. 2016), which may indicate how poorly known G. dentata gen. et comb. nov. is. However, it should be noted that details of how lice were identified are not always given in the published literature and the reliability of some records may be doubtful. This is especially the case for those species that are reported in anomalous regions of the host's body. For instance, lice in the genus Lipeurus are normally reported from the wings and tail of the host (e.g., Trivedi et al. 1991; Gabaj et al. 1993; Ilyes et al. 2013), but sometimes reported exclusively from the host's head (Santos-Prezoto et al. 2003). Both Cuclotogaster heterographus and Gallancyra dentata gen. et comb. nov. are normally collected from the host's head (e.g., Peters 1935; Emerson 1956; Gabaj et al. 1993). It is therefore possible that some records of Lipeurus from the head of the hosts are misidentifications of either of these two species. It is also possible that Lipeurus records from the host's head are the result of the Drost effect (Eichler 1970), the observation that after the host dies, lice typically abandon their natural microhabitats and move to the host's head. Greater care in reporting how chewing louse specimens were identified, and how the Drost-effect was prevented is needed.

Nevertheless, in large areas of the host's introduced range, this lack of records is likely genuine. For instance, the most densely surveyed countries in Africa are Nigeria and Ethiopia, with 20 and 12 published surveys of domestic chicken lice, respectively. No specimens of G. dentata gen. et comb. nov. have been reported, despite collectively covering several thousand chickens. Similarly, no specimens of this louse species have been found in numerous surveys of chicken in Turkey, Iran, and Pakistan (Table 1); the specimens from Sikkim we examined appear to be the first record of this species from India, despite at least nine surveys having been conducted.

\section{Chewing lice originating from other hosts}

Apart from occasional stragglers recorded from domestic chicken kept in mixed poultry flocks (Table 2; Campanulotes compar (Burmeister, 1838), Chelopistes meleagridis (Linnaeus, 1758), Colpocephalum turbinatum Denny, 1842, Goniodes microthorax (Stephens, 1829)), several species of ischnoceran 
lice on chicken are suspected to have originated from other hosts and subsequently become widely established. Two recently described species (Menacanthus longiscleritus Naz \& Rizvi, 2016 and Amyrsidea saudiensis Alahmed et al., 2017) are not discussed further here, as both are only known from their type localities, and it cannot be excluded that they represent stragglers from different host species.

The most common sources of presumed non-native lice found on chicken are guineafowl (Numididae). Of the 22 species of chewing lice reported from domestic chicken, five species are also known from at least some species of guineafowl (Amyrsidea powelli (Bedford, 1920), Menacanthus numidae (Giebel, 1874), Goniocotes maculatus (Taschenberg, 1882), Goniodes gigas (Taschenberg, 1879), Lipeurus tropicalis Peters, 1931). Of these, only G. gigas and L. tropicalis appear to be widely distributed outside the native range of guineafowl (Figs 1-2). Of the remaining three species, A. powelli has been reported from Nigeria (Fabiyi 1986), M. numidae from South Africa (Bedford 1924), France (Séguy 1944) and Spain (Martin Mateo 1973, 1974; Martin Mateo et al. 1980), and apart from the original description of G. maculatus, the only subsequent report from domestic chicken appears to be from Poland (Müller 1927); however, the identification of this record is dubious as no details are given.

Lipeurus tropicalis appears to be limited to tropical areas in Africa, the Neotropics, and the Indian subcontinent (Fig. 2). This may suggest that some environmental factors are limiting its range. Arora \& Chopra (1957) and Saxena \& Agarwal (1982) have both reported that lower temperatures may impact the life span, egg-laying rate, and morphogenesis inside the egg of L. tropicalis, with the optimal temperature being $30-40^{\circ} \mathrm{C}$, and the optimal relative humidity $80-85 \%$, with decreasing temperatures decreasing both life span and daily egg-laying rate. Agarwal \& Saxena (1979) showed that these two factors had a clear impact on population size of $L$. tropicalis over the year. These two factors may be the reason L. tropicalis is absent in parts of the world where the temperature or humidity are more disadvantageous than in India. However, Fabiyi (1996) did not find any pattern of preference for different climatic zones in Nigerian L. tropicalis.

In contrast, Goniodes gigas occurs as far north as Sweden, and has been found on every larger landmass in the world (Tabel 1; Fig. 1). Buriro \& Akbar (1978) suggested that G. gigas is highly adaptable to different climatic zones, but also stated that the species appeared to prefer drier habitats. Fabiyi (1996) only found G. gigas in areas with a short humid season, suggesting that G. gigas may prefer drier climates. This may seem counter-intuitive, as chewing lice obtain all their water from the air, using a specialized water-uptake system (Rudolph 1983). However, similar biogeographical patterns are known from lice in the genus Brueelia, which may also occur primarily in areas with low ambient humidity (Bush et al. 2009). Notably, Conci (1956) managed to raise G. gigas in temperature and humidity conditions similar to those mentioned above for L. tropicalis. As shown in Fig. 1, G. gigas is known across a large range of ambient humidities and temperatures, and may be very adaptable. However, many records are from domestic chicken in poultry farms indoors, which may skew the distributional data.

Emerson (1956) noted that the closest relatives of Cuclotogaster heterographus (Nitzsch [in Giebel], 1866) all occur on Alectoris Kaup, 1829 partridges around the Mediterranean. Other species of Cuclotogaster Carriker, 1936 are also primarily found on primarily dry-land hosts such as francolins (Tendeiro 1958; Price et al. 2003), suggesting that lice in this genus are also adapted to lower humidities. Based on this observation, Emerson (1956) suggested that the original host of $C$. heterographus might not be chicken, but some species of Alectoris partridge. All the subspecies of $C$. heterographus described by Clay (1938) from partridges are today treated as separate species (Price et al. 2003), but no thorough revision of the genus has been published. Conci (1952) found that the optimal temperature for survival of C. heterographus was $35.5-36.5^{\circ} \mathrm{C}$. The geographical range of $C$. heterographus appears to be global (Fig. 2), but reports from the Neotropics, Sub-Saharan Africa, and the native Southeast Asian 
range of chicken are rare. Fabiyi (1996) found Nigerian chicken to be parasitized by the closely related Cuclotogaster occidentalis (Tendeiro, 1954), which likely originates from some species of francolin.

Menacanthus stramineus has been found from several subspecies of wild turkey (Emerson 1956), which is likely the natural host of this louse species. Emerson (1956) stated that the species has never been found on any other wild host species, and that it readily transfers from one host to another in mixed poultry flocks. DeVaney et al. (1980) showed that this dispersal can occur very rapidly. Emerson (1956) assumed that this species was global in range. Fabiyi $(1986,1996)$ found no specimens in Nigeria, but the species has been reported from Nigeria, e.g., by Okaeme (1988). The overall range of this species spans almost the entire range of chicken (Fig. 3), and its absence in some regions may be due to patchiness in distribution, or low numbers of sampled birds. Notably, M. stramineus has also locally established itself on other hosts, such as Numida melagris (Linnaeus, 1758) (Okaeme 1988) and Pavo cristatus Linnaeus, 1758 (Nasser et al. 2015).

Lagopoecus sinensis (Sugimoto, 1930) was not included in the key of lice from domestic chicken by Emerson (1956), but has been reported from chicken in China and Taiwan at least three times (Sugimoto 1930; Emerson 1957; Arnold 2008) and never from any other host species. This may suggest that chicken is a natural host of this louse species, but Arnold (2008) stated that he could not separate this species reliably from Lagopoecus colchicus Emerson, 1949. Potentially, all records of this species may originate from stragglers from some pheasant species, but more research is needed.

\section{Possibility of competitive exclusion}

The rarity of $G$. dentata gen. et comb. nov. is peculiar, especially considering the discontinuous range of the species (Fig. 4), and the otherwise near-global range of most other species of ischnoceran chewing lice presumed to be native to chicken. Moreover, the fact that chewing louse species presumed to be native to guineafowl or turkey have not only become established on domestic chicken, but in some cases spread throughout the range of domesticated chicken, makes the absence of $G$. dentata gen. et comb. nov. from large parts of the host's range even more puzzling. Why has this louse species failed to capitalize on the huge range expansion of domestic chicken?

No data are available for the preferred environmental humidity or temperature of $G$. dentata gen. et comb. nov., but the known distribution suggests that the species cannot survive outside the warm and humid areas of the tropics. A few other species in the Oxylipeurus-complex are known from Africa (Ledger 1980), but the group otherwise occurs world-wide (Price et al. 2003). Overall, species in the Oxylipeurus-complex are typically absent from galliforms hosts that occur primarily in drier areas, but appear to occur on almost all groups of galliforms in the more humid parts of Southeast Asia (Price et al. 2003).

Notably, G. dentata gen. et comb. nov. occurs on the head of the host (Peters 1935), a microhabitat preference it shares with another chewing louse species known from chicken: Cuclotogaster heterographus (e.g., Hafez \& Madbouly 1966; Murillo \& Mullens 2016). Lice in the genus Cuclotogaster are common in Africa and other drier areas of the world (Ledger 1980; Price et al. 2003). Fabiyi (1996) found that Cuclotogaster occidentalis was entirely absent in areas of Nigeria with a long humid season. Even if most chewing lice are dependent on extracting water vapour from the air to survive, species of lice adapted to or thriving in very dry environments are known (Carillo et al. 2007; Bush et al. 2009).

Together, this suggests that $G$. dentata gen. et comb. nov. may be adapted to more humid areas, whereas $C$. heterographus is adapted to drier areas. If both species compete for the same resources (head feathers), this may give each species an advantage over the other depending on the external environment. Competition between different louse species on the same host is poorly known, but has 
been shown to occur in pigeons (Bush \& Malenke 2008). In one documented case, the competition between two congeneric louse species on the same host species is mediated by ambient humidity, with one species being better adapted to drier areas and the other to more humid areas (Malenke et al. 2011).

Direct competition between $C$. heterographus and $G$. dentata gen. et comb. nov. has not been demonstrated, but would explain the geographical distribution patterns of both species. Most reports of C. heterographus are from drier areas, such as the Middle East or the northern half of Africa, but the species is largely absent from the native range of wild chicken in Southeast Asia, and from Central America and the Caribbean, where G. dentata gen. et comb. nov. is established (Table 1; Figs 2, 4). In contrast, $G$. dentata gen. et comb. nov. is absent from the Middle East and all of Africa, where $C$. heterographus is frequently reported. The absence of $G$. dentata gen. et comb. nov. in, e.g., more humid areas of South America and Africa may be due to underreporting, or to unknown factors that limit its spread. More surveys are needed to establish whether G. dentata gen. et comb. nov. is circumtropical, or actually absent from these areas.

\section{Conclusions}

Due to the large number of published surveys of chewing lice on chicken, it is possible to outline the geographical range of these louse species. Some louse species appear to occur throughout the range of the host, including some species that likely originated from other host species. In contrast, other species of chewing lice show very limited geographical ranges. This may in some cases be affected by differences in the external environment, or by competition between chewing louse species occupying the same microhabitat on the bird.

The distribution records summarized here are more extensive and more complete than for any other bird-louse association. Moreover, much research has been performed to establish the environmental factors that influence life histories and survival of chewing lice on chicken. However, more detailed surveys of wild and domestic chicken across the tropics are sorely needed. In particular, more data is needed from more humid parts of Africa, as well as from drier areas in the outskirts of the native range of chicken, such as parts of China and India. More data are also needed from humid areas within the natural range of chicken, such as Myanmar, India and Indonesia, as well as from other host subspecies and other species of Gallus Brisson, 1760. We hope that the redescription and illustrations provided here will aid future efforts to understand the range and evolutionary history of Gallancyra dentata gen. et comb. nov.

\section{Acknowledgements}

Funding: this work was funded by the Guangdong Academy of Sciences (2018GDASCX-0809, 2017GDASCX-0107, 2018GDASCX-0107, GIABR-GJRC201701), the National Natural Science Foundation of China (31961123003) and Project 2019QN01N968 from the Pearl River Talent Recruitment Program (Guangdong Province). These agencies had no hand in the design or execution of this study, and we declare no conflict of interest. We would like to thank two anonymous reviewers for helpful comments on this manuscript. We would like to thank Dr. Vince Smith and Paul Brown (NHMUK) who hosted DRG in London and enabled the loan of specimens on which this manuscript is based.

\section{References}

Abdullah S.H. \& Mohammed A.A. 2013. Ecto and endo parasites prevalence in domestic chicken in Sulaimani region. Iraqi Journal of Veterinary Medicine 37: 149-155. 
Aboagy I.F., Korang E., Offeh A. \& Davis H.E. 2014. Assessment of ectoparasitic infestations in chickens (Gallus gallus domesticus) in the Sunyani West District, Ghana. Journal of Science and Technology 34: 11-17. https://doi.org/10.4314/just.v34i3.2

Adams R.J., Price R.D. \& Clayton D.H. 2005. Taxonomic revision of the Old World members of the feather louse genus Columbicola (Phthiraptera: Ischnocera), including descriptions of eight new species. Journal of Natural History 39: 3545-3618. https://doi.org/10.1080/00222930500393368

Adene D.F. \& Dipeolu O.O. 1975. Etude des parasites du sang et des ectoparasites des volailles domestiques à Ibadan, Province occidentale du Nigeria. Bulletin de Santé et Production animales en Afrique 23: 343-347.

Agarwal G.P. \& Saxena A.K. 1979. Studies on seasonal dynamics of Lipeurus lawrensis tropicalis Peters (Phthiraptera: Ischnocera) infesting poultry birds. Zeitschrift für Angewandte Entomologie 58: 470-476.

Ahaotu E.O., Akinfemi A. \& Okorie K.C. 2019. Economic importance and widespread of ectoparasites infestation in indigenous chickens (Gallus gallus domesticus). A study from selected local government councils and states in Nigeria. Sustainability, Agri, Food and Environmental Research 7: 17-31. https://doi.org/10.7770/safer-V0N0-art1661

Alahmed A., Aldryhim Y., Shobrak M. \& Nasser M. 2017. A new species of the genus Amyrsidea (Phthiraptera: Amblycera: Menoponidae) parasitizing domestic chickens in Saudi Arabia. Zootaxa 4238: 253-257. https://doi.org/10.11646/zootaxa.4238.2.5

Aldemir O.S. 2004. Kars ilinde tavuklarda bulunan ektoparazitler. Türkiye Parazioloji Dergesi 28: 154 157.

Aldryhim Y.N. 1991. Mallophaga of the domestic chicken in the central region of Saudi Arabia. Emirates Journal of Agricultural Science 3: 143-150.

Alemu N., Muktar Y., Kassaye D. \& Hiko A. 2015. Prevalence of lice and fleas in backyard chickens of Bishoftu Town, Ethiopia. American-Eurasian Journal of Agricultural and Environmental Sciences 15: 2136-2142.

Aliraqi R.A. \& Amin K.A.H. 2007. Identify the biting lice attacking the chickens in Arbil governorate. Iraqi Journal of Veterinary Sciences 21: 13-21. https://doi.org/10.33899/ijvs.2007.5629

Al-Shaibani K.T.M., Al-Abodi H.R.J. \& Mahmood H.R. 2018. Effect of two species of ticks and lice on some blood and biochemical parameters and their role in the transmission of Toxoplasma gondii to turkey Meleagris gallopavo during spring and summer seasons in Al-Diwaniyah province - Iraq. Journal of Global Pharma Technology 10: 273-280.

Amede Y., Tilahun K. \& Bekele M. 2011. Prevalence of ectoparasites in Haramaya University intensive poultry farm. Global Veterinarian 7: 264-269.

Amin-Babjee S.M., Lee C.C. \& Mahmood A.A. 1997. Prevalence of ectoparasite infection in different age groups of village chickens. Jurnal Veterinari Malaysia 9: 55-59.

Ansari R.A.M. 1946. Mallophaga found on domestic fowl Gallus domesticus Linn., in the Punjab. Indian Journal of Entomology 5: 129-142.

Armstrong M.H., Braun E.L. \& Kimball R.T. 2001. Phylogenetic utility of avian ovomucoid intron G: a comparison of nuclear and mitochondrial phylogenies in Galliformes. Auk 118: 799-804.

https://doi.org/10.1093/auk/118.3.799

Arnold D.C. 2008. The pheasant group of the genus Lagopoecus (Phthiraptera: Ischnocera: Philopteridae). Journal of the Kansas Entomological Society 81: 153-160. https://doi.org/10.2317/JKES-711.12.1 
Arora G.L. \& Chopra N.P. 1957. Some observations on the biology of Lipeurus tropicalis Peters. Research Bulletin of the Punjab University, Zoology 130: 485-491.

Ashenafi H. \& Yimer E. 2005. Ectoparasites of local scavenging chickens of central Ethiopia. Ethiopian Journal of Science 28: 69-74.

Backlund H.O. 1934. A contribution to the knowledge of the poultry-lice in Finland. Memoranda Societatis pro Fauna et Flora Fennica 10: 42-46.

Bala A.Y., Anka S.A., Waziri A. \& Shehu H. 2011. Preliminary survey of ectoparasites infesting chickens (Gallus domesticus) in four areas of Sokoto Metropolis. Nigerian Journal of Basic and Applied Science 19: 173-180.

Banda Z. 2011. Ectoparasites of indigenous Malawi chickens. Australian Journal of Basic and Applied Sciences 5: 1454-1460.

Bassey S.E. \& Marroh R. 2018. A survey of ectoparasites in the free range domestic fowl, Gallus gallus domesticus, in Amassoma, Bayelsa State, Nigeria. Journal of Environment and Bio Research 2: 1-3.

Bedford G.A.H. 1924. The external parasites of poultry, with measures for their control. Journal of the Department of Agriculture of South Africa 9: 123-140.

Belihu K., Mamo A., Lobago F. \& Ayana D. 2009. Prevalence of ectoparasites in backyard local chickens in three agroeconomical zones on East Shoa, Ethiopia. Revue de Médecine vétérinaire 160: 537-541.

Bhat S.A., Wani M.Y., Khojuria J.K., Katoch R. \& Dhama K. 2014. A rare report of ectoparasites in backyard poultry in Jammu region: prevalence study and economic importance. Asian Journal of Animals and Veterinary Advances 9: 727-731. https://doi.org/10.3923/ajava.2014.727.731

Blagoveshtchensky D.I. 1940. Mallophages des animaux domestiques. Fauna de l'URSS 27: 1-89.

Blagoveshtchensky D.I. 1951. Mallophaga of Tadzhikistan. Parasitologieeskij Zbornik 13: 272-327.

Boyd E.M. 1951. A survey of parasitism of the starling Sturnus vulgaris L. in North America. Journal of Parasitology 31: 56-84. https://doi.org/10.2307/3273522

Brown N.S. \& Wilson G.I. 1975. A comparison of the ectoparasites of the house sparrow (Passer domesticus) from North America and Europe. American Midland Naturalist 94: 154-165.

https://doi.org/10.2307/2424546

Buriro S.N. \& Akbar S.S. 1978. Incidence and occurrence of ectoparasites of poultry in Pakistan. Zeitschrift för Angewandte Entomologie 86: 1-8. https://doi.org/10.1111/j.1439-0418.1978.tb01904.x

Bush S.E., Harbison C.W., Slager D.L., Peterson A.T., Price R.D. \& Clayton D.H. 2009. Geographic variation in the community structure of lice on Western Scrub-Jays. Journal of Parasitology 95: 10-13. https://doi.org/10.1645/GE-1591.1

Bush S.E. \& Malenke J.R. 2008. Host defence mediates interspecific competition in ectoparasites. Journal of Animal Ecology 77: 558-564. https://doi.org/10.1111/j.1365-2656.2007.01353.x

Camacho-Escobar M.A., Arroyo-Ledezma J., Avila-Serrano N.Y., Jerez-Salas M.P., Sanchez-Bernal E.I. \& García-López J.C. 2014. Ectoparasites and their damage in backyard turkeys in Oaxaca's coast. European Journal of Veterinary Medicine 7: 1-18.

Carillo C.M., Valera F., Barbosa A. \& Moreno E. 2007. Thriving in an arid environment: high prevalence of avian lice in low humidity conditions. Écoscience 14: 241-249.

Černy V. 1969. Mallophaga of domestic chickens from Cuba. Folia Parasitologica (Praha) 16: 40.

Chopra N.P. 1968. Mallophaga found on Gallus domesticus L. in Punjab, India. Research Bulletin (N.S.) of the Panjab University 19: 405-412. 
Clay T. 1938. A revision of the genera and species of Mallophaga occurring on gallinaceous hosts. Part I. Lipeurus and related genera. Proceedings of the Zoological Society of London 108: 108-204. https://doi.org/10.1111/j.1096-3642.1938.tb00026.x

Clay T. 1940. Genera and species of Mallophaga occurring on gallinaceous hosts.-Part II. Goniodes. Proceedings of the Zoological Society of London 110: 1-120.

https://doi.org/10.1111/j.1469-7998.1940.tb00027.x

Clay T. 1976. Geographical distribution of the avian lice (Phthiraptera): a review. Journal of the Bombay Natural History Society 71: 536-547.

Clements J.F., Schulenberg T.S., Iliff M.J., Roberson D., Fredericks T.A., Sullivan B.L. \& Wood C.L. 2019. The eBird/Clements checklist of birds of the world: ver. 2019. Available from http://www.birds.cornell.edu/clementschecklist/download/ [accessed 23 Sep. 2019].

Conci C. 1952. L'allevamento in condizioni spermentali dei Mallofagi I.-Cuclotogaster heterographus Nitzsch. Bolletin dei Musei e Instituto Biologica, Universitaire de Genova 24: 17-40.

Conci C. 1956. L'allevamento in condizioni spermentali dei Mallofagi II.- Stenocrotaphus gigas (Taschenberg). Memoria della Societa Entomologica Italiana 36: 133-150.

Cruz M.I., Figueroa C.J.A., Quintero M.M.T. \& Alcalá C.Y. 2013. Ectoparásitos de aves en explotaciones de traspatio (Gallus gallus domesticus, y Meleagris gallopavo) du una region del sur de México. Revista Ibero-Latinamericano de Parasitologica 72: 185-189.

DeVaney J.A., Quisenberry J.H., Doran B.H. \& Bradley J.W. 1980. Dispersal of the northern fowl mite, Ornithonyssus sylviarum (Canestrini and Fanzago), and the chicken body louse, Menacanthus stramineus (Nitzsch), among thirty strains of egg-type hens in caged laying houses. Poultry Science 59: 1745-1749. https://doi.org/10.3382/ps.0591745

De Zayas F. 1941. Los Malófagos de las aves domésticas en Cuba. Memorias de la Sociedad Cubana de Historia Natural "Felipe Poey" 15: 201-209.

Dik B., Yaman M., Köse M. \& Güibaçe S. 1999. Determination of Mallophaga species on poultry in Konya. Türkiye Parazitoloji Dergisi 23: 327-330.

Dik B., Per E., Erciyas Yavuz K. \& Yamaç E. 2015. Chewing lice (Phthiraptera: Amblycera, Ischnocera) species found on birds in Turkey, with new records and a new host association. Turkish Journal of Zoology 39: 790-798. https://doi.org/10.3906/zoo-1411-45

Do Carmo Rezende L., da Silva Martins N.R., Teixeira C.M., de Oliveira P.R. \& Cunha L.M. 2016. Epidemiological aspects of lice (Menacanthus species) infections in laying hen flocks from the State of Minas Gerais, Brazil. British Poultry Science 57: 44-50.

https://doi.org/10.1080/00071668.2015.1127893

Döner A. \& Yaman M. 2015. Mallophaga species in the chickens of Mardin Province. Van Veterinary Journal 26: 7-12.

Dyke G.J., Gulas B.E. \& Crowe T.M. 2003. Suprageneric relationships of galliform birds (Aves, Galliformes): a cladistic analysis of morphological characters. Zoological Journal of the Linnean Society 137: 227-244. https://doi.org/10.1046/j.1096-3642.2003.00048.x

Edosomwan E.U. \& Igetei E.J. 2018. Ecto- and endo-parasites of domestic birds in Owan west, east and Akoko-Edo in Edo state of Nigeria. International Journal of Zoology Studies 3: 28-35.

Edosomwan E.U., Olumese E.R. \& Igetei E.J. 2011. A study of ecto- and endo parasites of domestic birds in Etsako Municipality, Edo North of Nigeria. Niseb Journal 11: 209-216. 
Eichler W. 1970. Mallophagen-Sammeltechnik und Drost-Effekt bei Allobrueelia amsel. Angewandte Parasitologie 11: 111-112.

Ekpo U.F., Ogbooye A.A., Oluwole A.S. \& Takeet M. 2010. A preliminary survey on the parasites of free range chicken in Abeokuta, Ogun State, Nigeria. Journal of Natural Sciences, Engineering and Technology 9: 123-130.

El-Aw M.A., Draz K.A., Abdel-Hamed A.E. \& Awad M.A. 2008. Identification of biting lice species on infected domestic chickens and their distribution on different body regions. Journal of Agricultural and Environmental Sciences, Alexandria University, Egypt 7: 131-143.

Emerson K.C. 1956. Mallophaga (chewing lice) occurring on the domestic chicken. Journal of the Kansas Entomological Society 29: 63-79.

Emerson K.C. 1957. Notes on Lagopoecus sinensis (Sugimoto) (Philopteridae, Mallophaga). Journal of the Kansas Entomological Society 30: 9-10.

Emerson K.C. \& Elbel R.E. 1957a. New records of Mallophaga from wild chickens. Journal of Parasitology 43: 381-382.

Emerson K.C. \& Elbel R.E. 1957b. New species and records of Mallophaga from gallinaceous birds of Thailand. Proceedings of the Entomological Society of Washington 59: 232-243.

Emmanuel O.I., Anyebe A.A., Agbo O.E., Odeh U.P., Love O. \& Agogo I.M. 2017. A preliminary survey of ectoparasites and their predilection sites on some livestock sold in Wadata Market, Makurdi, Nigeria. American Journal of Entomology 1: 11-15.

Eslami A., Ghaemi P. \& Rahbari S. 2009. Parasitic infections of free-range chickens from Golestan province, Iran. Iranian Journal of Parasitology 4: 10-14.

Fabiyi J.P. 1980. Survey of lice infesting domestic fowl on the Jos Plateau, northern Nigeria. Bulletin of Animal Health and Production in Africa 28: 215-219.

Fabiyi J.P. 1986. Exclusion in Nigeria of chickens and guinea-fowl from the host range of Menacanthus stramineus (Mallophaga: Insecta). Revue d'Elevage et de Médecine veterinaire des Pays tropicaux 39: $377-379$.

Fabiyi J.P. 1996. Association between duration of humid season and geographical distribution patterns of different species of chewing lice (Mallophaga: Insecta) infesting domestic chicken in Nigeria. Journal of Parasitology 82: 1034-1036. https://doi.org/10.2307/3284220

Ferreira C.G.T., Mafra C., Bezerra A.C.D.S., de Carvalho O.V., Junior A.S. \& de Almeida M.R. 2013. Campanulotes compar (Burmeister, 1838) (Phthiraptera: Ischnocera) in chickens (Gallus gallus domesticus) from Rio Grande do Norte State, Brazil. The reemergence of an ectoparasite? Veterinary Parasitology 195: 203-204. https://doi.org/10.1016/j.vetpar.2012.12.047

Ferrero A.A., Gutiérrez M.M., García S.H. \& Castro D. 2004. Phthiraptera (Arthropoda, Insecta) en Gallus gallus (Galliformes, Phasianidae) en criaderos de áreas urbanas y suburbanas de la Ciudad de Bahía Blanca, Provincia de Buenos Aires, Argentina. Entomologie y Vectores 11: 297-303.

Figuieredo S.M., Guimarães J.H. \& Gama N.M.S.Q. 1993. Biologia e ecologia de malófagos (Insecta, Phthiraptera) em aves de postura de granjas industriais. Revista Brasileira de Parasitologica Veterinária 2: $45-51$.

Gabaj M.M., Beesley W.N. \& Awan M.A.Q. 1993. Lice on farm animals in Libya. Medical and Veterinary Entomology 7: 138-140. https://doi.org/10.1111/j.1365-2915.1993.tb00666.x

Galloway T.D. \& Palma R.L. 2008. Serendipity with chewing lice (Phthiraptera: Menoponidae, Philopteridae) infesting rock pigeons and mourning doves (Aves: Columbiformes: Columbidae) in 
Manitoba, with new records for North America and Canada. Canadian Entomologist 140: 208-218. https://doi.org/10.4039/n07-041

George J.B.D., Otobo S., Ogunleye J. \& Adedimimiyi B. 1992. Louse and mite infestation in domestic animals in northern Nigeria. Tropical Animal Health and Production 24: 121-124.

Gharsan F.N. \& Elhassan S.A.M. 2019. Prevalence of infection with ectoparasites among chickens of Albaha Region-Kingdom of Saudi Arabia. Journal of Agriculture and Food Technology 9: 1-6.

Giebel C. 1866. Die im zoologischen Museum der Universität Halle aufgestellten Epizoen nebst Beobachtungen über dieselben. Zeitschrift für die Gesammten Naturwissenschaften 28: 353-397.

González-Acuña D., Lara J. \& Cicchino A. 2009. Nuevos registros de piojos (Insecta: Phthiraptera) en aves domesticas y ornamentals en Chile. Archivos de Medicina Veterinaria 41: 181-184.

https://doi.org/10.4067/S0301-732X2009000200013

Guerra R. de M.S.N. de C., Chaves E.P., Passos T.M.G. \& dos Santos A.C.G. 2008. Espécies, sítios de localização, dinâmica de estrutura de populações de Malófagos em galinhas caipiras (Gallus gallus L.) criada na Ilha de São Luis, Ma. Neotropical Entomology 37: 259-264.

https://doi.org/10.1590/S1519-566X2008000300004

Gustafsson D.R. \& Bush S.E. 2017. Morphological revision of the hyperdiverse Brueelia-complex (Insecta: Phthiraptera: Ischnocera: Philopteridae) with new taxa, checklists and generic key. Zootaxa 4313: 1-443. https://doi.org/10.11646/zootaxa.4313.1.1

Gustafsson D.R., DiBlasi E., Olsson U., Najer T., Sychra O. \& Bush S.E. 2019. Checklist and key to the lice (Insecta: Phthiraptera) of Sweden. Entomologisk Tidskrift 139: 205-394.

Gustafsson D.R., Lei L., Chu X. \& Zou F. 2020. Review of the Chinese species of the Oxylipeuruscomplex (Phthiraptera: Philopteridae), with descriptions of two new genera and five new species. Zootaxa 4742: 201-255. https://doi.org/10.11646/zootaxa.4742.2.1

Hackman W. 1994. Mallofager (Phthiraptera: Mallophaga) som parasiterar på Finlands fågelarter. Memoranda Societatis pro Fauna et Flora Fennica 70: 35-70.

Hafez M. \& Madbouly M.H. 1966. Bird lice infesting domestic animals in Egypt. Bulletin of the Entomological Society of Egypt 50: 181-213.

Hernandez-Divers S.M., Villegas P., Prieto F., Unda J.C., Stedman N., Ritchie B., Carroll R. \& Hernandez-Divers S.J. 2006. A survey of selected avian pathogens of backyard poultry in northwestern Ecuador. Journal of Avian Medicine and Surgery 20: 147-158. https://doi.org/10.1647/2005-015R.1

Hernandez-Divers S.M., Villegas P., Jimenez C., Hernandez-Divers S.J., Garcia M., Riblet S.M., Carroll C.R., O'Connor B.M., Webb J.L., Yabsley M.J., Williams S.M. \& Sanchez S. 2008. Backyard chicken pose a disease risk for Neotropic birds in Costa Rica. Avian Diseases 52: 558-566. https://doi.org/10.1637/8298-032808-Reg.1

Hohorst W. 1939. Die Mallophagen des Haushuhnes und ihre Eigelege. Veterinär-medizinische Nachrichten 4-6: 1-88.

Ikpeze O.O., Amagba I.C. \& Eneanya C.I. 2008. Preliminary survey of ectoparasites of chicken in Awka, South-Eastern Nigeria. Animal Research International 5: 848-851.https://doi.org/10.4314/ari.v5i2.48745

Ilyes M., Ahmed B., Kheira S., Henene D. \& Fouzi M. 2013. Prevalence and distribution of chewing lice (Phthiraptera) in free range chickens from the traditional rearing system in the Algerian North East, area of El-Tarf. International Journal of Poultry Science 12: 721-725. https://doi.org/10.3923/ijps.2013.721.725

Inci A., Yildirim A., Dik B. \& Düzlü Ö. 2010. Current knowledge of Turkey’s louse fauna. Turkiye Parazitoloji Dergasi 34: 212-220. https://doi.org/10.5152/tpd.2010.17 
Jansson D., Fossum O., Engelsen P.E., Christensson B., Andersson B. \& Christensson D. 2004. Parasitförekomst hos tamhöns i svenska hobbyflockar. Svensk Veterinärtidskrift 11: 11-17.

Johnson K.P., Williams B.L., Drown D.M., Adams R.J. \& Clayton D.H. 2002. The population genetics of host specificity: genetic differentiation in dove lice (Insecta: Phthiraptera). Molecular Ecology 11: 25-38. https://doi.org/10.1046/j.0962-1083.2001.01412.x

Kaboudi K., Romdhane R.B., Salem A.B. \& Bouzouaia M. 2019. Occurrence of ectoparasites in backyard domestic chickens (Gallus gallus domesticus) in the Northeast of Tunisia. Journal of Animal Health and Production 7: 92-98. https://doi.org/10.17582/journal.jahp/2019/7.3.92.98

Kebede A., Abede B. \& Zewdie T. 2017. Study on prevalence of ectoparasites on poultry in and around Jimma Town. European Journal of Biological Sciences 9: 18-26.

Kéler S. von 1939. Baustoffe zu einer Monographie der Mallophagen. II. Teil: Überfamilie der Nirmoidea (1). Die Familien Trichophilopteridae, Goniodidae, Heptapsogastridae. Nova Acta Leopoldina. Abhandlungen der Kaiserlische Leopoldinisch-Carolinisch Deutschen Akademie der Naturforscher, Neue Folge 8: 1-254.

Kéler S. von. 1958. The genera Oxylipeurus Mjöberg and Splendoroffula Clay and Meinertzhagen (Mallophaga). Deutsche Entomologische Zeitschrift, Neue Folge 5: 300-347.

Khan M.N., Nadeem M., Iqbal Z., Sajid M.S. \& Abbas R.Z. 2016. Lice infestation in poultry. International Journal of Agriculture and Biology 5: 213-216.

Kimball R.T. \& Braun E.L. 2008. A multigene phylogeny of Galliformes supports a single origin of erectile ability in non-feathered facial traits. Journal of Avian Biology 39: 438-445.

https://doi.org/10.1111/j.0908-8857.2008.04270.x

Köroglu E., Saki C.E., Aktas M., Dumanli N. \& Angin M. 1999. Distribution of lice in chicken in Elazig region. Firat University Veterinary Journal of Health Sciences 13: 57-60.

Lawal J.R., Bello A.M., Balami S.Y., Wakil Y., Yusuf Z.B., Dauda J., Msheila E.S., Mana H.P., Adam M.K. \& Biu A.A. 2016. Prevalence and economic significance of ectoparasites infestation in village chicken (Gallus gallus domesticus) in Gombe, northeastern Nigeria. Direct Research Journal of Agriculture and Food Science 4: 94-103.

Lawal J.R., Yusuf Z.B., Dauda J., Gazali Y.A. \& Biu A.A. 2017. Ectoparasites infestation and its associated risk factors in village chickens (Gallus gallus domesticus) in and around Potiskum, Yobe State, Nigeria. Journal of Animal Husbandry and Dairy Science 1: 8-19.

Ledger J.A. 1980. The arthropod parasites of vertebrates in Africa south of the Sahara. Volume IV. Phthiraptera (Insects). Publications of the South African Institute for Medical Research 56. South Africa Institute for Medical Research, Johannesburg.

Liu S. 1985. Taxonomic study on lice (Mallophaga) in Sichuan Province. Sichuan Animal and Veterinary Journal 2: 7-10.

Lonc E., Modrzejewska M., Saxena A.K., Złotorzycka J. \& Trivedi M.C. 1992. Morphometric variability of the mallophagan populations (Insecta, Phthiraptera, Amblycera and Ischnocera) from the Polish and Indian domestic fowl (Gallus gallus f. dom.). Rudolstädter naturhistorische Schriften 4: 59-70.

Love O., Johnny R. \& Valentine I.C. 2017. A study of the prevalence and abundance of chewing lice (Phthiraptera) in selected poultry farms in Benin City, Edo State. International Journal of Animal Science and Technology 1: 35-42.

MacCreary D. \& Catts E.P. 1954. Ectoparasites of Delaware poultry including a study of litter fauna. University of Delaware Agricultural Experiment Station Technical Bulletin 307: 4-17. 
Maldonado-Cipriles J. \& Miro-Mercado J. 1978. The wing louse, Lipeurus caponis (L.) (Mallophaga: Philopteridae) attacking poultry in Puerto Rico. Journal of Agriculture of the University of Puerto Rico 62: 309-310.

Malenke J.R., Newbold N. \& Clayton D.H. 2011. Condition-specific competition governs the geographic distribution and diversity of ectoparasites. American Naturalist 177: 522-234.

Mansur K.M., Mahmoud N M., Allamoushi S.M. \& El Aziz M.M.A. 2019. Biodiversity and prevalence of chewing lice on local poultry. Journal of Dairy, Veterinary and Animal Research 8: 26-31.

Manuel M.F. \& Anceno T.A. 1981. Distribution of lice (Mallophaga) on the body of native chickens (Gallus gallus domesticus). Philippine Journal of Veterinary Medicine 20: 50-57.

Marín-Gómez S.Y. \& Benavides-Montaño J.A. 2007. Parásitos en aves domesticas (Gallus domesticus) en el Noroccidente de Colombia. Veterinaria y Zootecnia 1: 43-51.

Marniche F., Milla A., Dik B., Laloui F., Medkour M., Nadjai B., Noumi H. \& Zerouki S. 2017. Parasites encountered in captivity birds: case of infested blue peacock - Pavo cristatus Linnaeus, 1758 (Aves: Phasianidae) in different localities from Algeria. Oltenia, Studii si communicari, Stiintele Naturii 33: 79-84.

Martín-Mateo M.P. 1973. Especies españolas de Menoponidae (Mallophaga: Insecta) parásitas de aves domésticas. Revista Ibérica de Parasitología 33: 281-294.

Martín-Mateo M.P. 1974a. El género Menacanthus (Mallophaga Insecta) in España. Boletín de la Real Sociedad Española de Historia Natural (Sección Biológica) 72: 165-179.

Martín-Mateo M.P. 1974b. Observaciones sobre algunas especies de Menoponidae (Mallophaga: Insecta) parásitas de aves domesticas en España. Vie et Millieu, Série C 24: 151-158.

Martín-Mateo M.P., Albalá F. \& Sánchez Acedo C. 1980. Malófagos ectoparasites de aves de la provincial de Zaragoza. Graellsia, Revista de Entomólogos Ibéricos 34: 121-145.

Martínez de Chirinos N.I., Chirinos Á.R., Hinestroza Y., Inicarte M.F., Manco M. \& Meléndez A. 2001. Prevalencia de ectoparasites en gallinas de corral (Gallus gallus domesticus) del municipio San Fransisco, Estado Zulia, Venezuela. Revista Cientéifica de la Facultad de Ciencias Veterinarias 11: 348-350.

Mata W., Galgalo W. \& Jilo K. 2018. Prevalence of the major ectoparasites of poultry in extensive and intensive farms in Jimma, southwestern Ethiopia. Journal of Parasitology and Vector Biology 10: 87-96.

Matsudaira Y. \& Kaneko K. 1969. Notes on biting lice (Mallophaga) collected from domestic fowl in Japan. Japanese Journal of Sanitary Zoology 20: 219-229.

Meguini M.N., Righi S., Zeroual F., Saidani K. \& Benakhla A. 2018. Inventory of lice of mammals and farmyard chicken in North-eastern Algeria. Veterinary World 11: 386-396.

https://doi.org/10.14202/vetworld.2018.386-396

Mekuria S. \& Gezahegn E. 2010. Prevalence of external parasites of poultry in intensive and backyard chicken farms at Wolayta Soddo town, southern Ethiopia. Veterinary World 3: 533-538.

Mey E. 1990. Zur Taxonomie der auf Großfußhühnern (Megapodiidae) schmarotzenden OxylipeurusArten (Insecta, Phthiraptera, Ischnocera: Lipeuridae). Zoologische Abhandlungen Staatlisches Museum für Tierkunde Dresden 46: 103-116.

Mey E. 2003. Verzeichnis der Tierläuse (Phthiraptera) Deutschlands. Entomofauna Germanica 6: 72-129.

Mimioglu M.M. 1952. Türkite'de Tavuklarda Mallophaga'lar (tavuk bitleri) ve en uygun mücadele metotlari üzerinde arastirmalar. Ankara Universitesi Veteriner Fakültesi Yayinlari 32: 1-60. 
Mirzaei M., Ghashghaei O. \& Yakhchali M. 2016. Prevalence of ectoparasites of indigenous chickens from Dalahu region, Kermanshah province, Iran. Turkiye Parazitoloji Dergasi 40: 13-16.

https://doi.org/10.5152/tpd.2016.4185

Mishra S., Pednekar R. \& Gatne M. 2016a. A comparative study of region specificity in bird louse in organized and unorganized sector of Mumbai. International Journal of Science, Environment 5: 35063511 .

Mishra S., Pednekar R. \& Gatne M. 2016b. Species wise and breed wise prevalence of lice infestation in poultry of Mumbai region, India. Journal of Livestock Science 7: 293-296.

Mjöberg E. 1910. Studien über Mallophagen und Anopluren. Arkiv för Zoologi 6: 1-296.

Morariu S., Braila P., Cosoroaba I., Darabus G., Oprescu I., Mederle N., Ilie M. \& Morariu F. 2008. The prevalence of mallophagean species on gallinaceous birds from Caras-Severin County. Lucrari Stiintifice Medicina Veterinara 41: 443-448.

Moyer B.R., Drown D.M. \& Clayton D.H. 2002. Low humidity reduces ectoparasite pressure: implications for host life history evolution. Oikos 97: 223-228. https://doi.org/10.1034/j.1600-0706.2002.970208.x

Moyo S., Masika P.J. \& Moyo B. 2015. A diagnostic survey of external parasites of free-range chickens, in the rural areas of Eastern Cape, South Africa. International Journal of Agricultural Science and Veterinary Medicine 3: 1-9.

Mukaratirwa S. \& Hove T. 2009. A survey of ectoparasites, cestodes and management of free-range indigenous chickens in rural Zimbabwe. Journal of the South African Veterinary Association 80: 188191.

Mukaratirwa S. \& Khumalo M.P. 2012. Prevalence of chewing lice in free-range chickens from selected rural localities of KwaZulu-Natal, South Africa. International Journal of Applied Research in Veterinary Medicine 10: 85-89.

MüllerT. 1927. Beobachtungen über die Mallophagen der Frischen Nehrung. Bericht des Westpreussischen Botanisch-Zoologischen Vereins 49: 1-44.

Mungube E.O., Bauni S.M., Tenhagen B.-A., Wamae L.W., Nzioka S.M., Muhammed L. \& Nginyi J.M. 2008. Prevalence of parasites of the local scavenging chickens in a selected semi-arid zone of Eastern Kenya. Tropical Animal Health and Production 40: 101-109. https://doi.org/10.1007/s11250-007-9068-3

Murillo A.C. \& Mullens B.A. 2016. Diversity and prevalence of ectoparasites on backyard chicken flocks in California. Journal of Medical Entomology 53: 707-711. https://doi.org/10.1093/jme/tjv243

Nadeem N., Khan M.N., Iqbal Z., Sajid M.S., Arshad M. \& Yaseen M. 2007. Determinants influencing prevalence of louse infestations on layers of District Faisalabad (Pakistan). British Poultry Science 48: 546-550. https://doi.org/10.1080/00071660701573086

Naheed A. \& Adna B. 2004. Chewing lice (Insecta: Mallophaga) of domestic chicken at Jand (District Attock). Proceedings of the Pakistan Congress of Zoology 24: 115-123.

Nasser M., Al-Ahmed A., Shobrak M. \& Aldryhim Y. 2015. Identification key for chewing lice (Phthiraptera: Amblycera, Ischnocera) infesting the Indian Peafowl (Pavo cristatus) with one new country record and new host record for Saudi Arabia. Turkish Journal of Zoology 38: 1-7.

https://doi.org/10.3906/zoo-1312-44

Natala A.J., Okubanjo O.O., Ulayi B.M., Owolabi Y.N., Jatau I.D. \& Yusuf K.H. 2009. Ectoparasites of domestic animals in Northern Nigeria. Journal of Animal and Plant Sciences 3: 238-242. 
Naz S. \& Rizvi S.A. 2016. A new species of genus Menacanthus Neumann, 1912 (Phthiraptera: Amblycera: Menoponidae) on Gallus gallus L. from Sindh, Pakistan. International Journal of Advanced Research in Biological Sciences 3: 142-148.

Naz S., Rajpar A.A. \& Chandio A.H. 2016. New records of some Phthiraptera (chewing lice) of birds from urban areas of Hyderabad, Sindh, Pakistan. Punjab University Journal of Zoology 31: 193-201.

Nitzsch C L. 1818. Die Familien und Gattungen der Thierinsekten (Insecta epizoica); als ein Prodromus einer Naturgeschichte derselben. E.F. Germar's Magazin der Entomologie 3: 261-318.

Noh Y.T., Back K.M. \& Moon I.H. 1989. Taxonomic studies on chewing lice (Mallophaga, Philopteridae) in Korea. Korean Journal of Entomology 19: 143-147.

Odenu R.A., Mohammed B.R., Simon M.K. \& Agbede R.I.S. 2016. Ecto-parasites of domestic chickens (Gallus gallus domesticus) in Gwagwalada Area Council, Abuja, Nigeria-West Africa. Alexandria Journal of Veterinary Sciences 51: 140-146. https://doi.org/10.5455/ajvs.220654

Okaeme A.N. 1988. Ectoparasites of guinea fowl (Numida meleagris galeata Pallas) and local domestic chicken (Gallus gallus) in southern Guinea savannah, Nigeria. Veterinary Research Communications 12: 277-280. https://doi.org/10.1007/BF00343245

Oliveira H.H., Ferreira I. \& Serra-Freire N.M. 1999. Fauna de Mallophaga (Insecta: Aptera) de ectoparasites em Gallus gallus L. e Columba livia L. amostrados no Rio de Janeiro - Brasil. Entomologíay Vectores, Rio de Janeiro 6: 509-515.

Orunç Ö. \& Biçek K. 2009. Van Yöresi Tavuklarinda Paraziter Fauna Tespiti. Türkiye Parazitoloji Dergisi 33: 162-164.

Palma R L. 2017. Phthiraptera (Insecta). A catalogue of parasitic lice from New Zealand. Fauna of New Zealand 76: 1-400. https://doi.org/10.7931/J2/FNZ.76

Palma R.L. \& Baker S C. 1996. Phthiraptera. In: Wells A. (ed.). Zoological Catalogue of Australia. 26: Psocoptera, Phthiraptera, Thysanoptera. CSIRO Publishing, Melbourne.

Paterson A.M. \& Gray R.D. 1997. Host-parasite cospeciation, host switching and missing the boat. In: Clayton D.H. \& Moore J. (eds) Host-Parasite Evolution: General Principles and Avian Models: 236-250. Oxford University Press, Oxford.

Paterson A.M., Palma R.L. \& Gray R.D. 1999. How frequently do avian lice miss the boat? Implications for coevolutionary studies. Systematic Biology 48: 214-223. https://doi.org/10.1080/106351599260544

Percy J., Pias M., Enetia B.D. \& Lucia T. 2012. Seasonality of parasitism in free range chickens from a selected ward of a rural district in Zimbabwe. African Journal of Agriculture Research 7: 3626-3631.

Permin A., Esmann J.B., Hoj C.H., Hove T. \& Mukaratirwa S. 2002. Ecto-, endo- and haemoparasites in free-range chickens in Goromonzi District in Zimbabwe. Preventive Veterinary Medicine 54: 213-224. https://doi.org/10.1016/S0167-5877(02)00024-7

Peters H.S. 1931. A new louse from domestic chickens (Mallophaga: Philopteridae). Entomological News 42: 195-199.

Peters H.S. 1935. A new chicken louse (Mallophaga: Philopteridae) from the Canal Zone. Ohio Journal of Science 35: 101-104.

Pisica C. 1985. Malofage (Mallophaga Nitzsch) parasite pe gaina (Gallus gallus domesticus L.). Analele stiintifice ale Universitatii “Alexandru Ioan Cuza” din Iasi, Sectia Biologie 31: 27-31. 
Portugaliza H.P. \& Bagot M.A. 2015. Different species of lice (Phthiraptera), fleas (Siphonaptera) and ticks (Ixodida) collected from livestock, poultry, reptile and companion animal in Leyte Island, Philippines. Livestock Research for Rural Development 27: 1-10.

Preiesov P. 1998. Survey of Mallophaga (Phthiraptera, Insecta) of poultry (Gallus domesticus) in Stara Zagora region (Bulgaria). Parasitology International 47 (Suppl. 1): 306.

Prelezov P.N. \& Koinarski T.S. 2006. Species variety and population structure of Mallophaga (Insecta: Phthiraptera) on chickens in the region of Stara Zagora. Bulgarian Journal of Veterinary Medicine 9: 193-200.

Price R.D. 1977. The Menacanthus (Mallophaga: Menoponidae) of the Passeriformes (Aves). Journal of Medical Entomology 14: 207-220.

Price R.D., Hellenthal R.A. \& Palma R.L. 2003. World checklist of chewing lice with host associations and keys to families and genera. In: Price R.D., Hellenthal R.A., Palma R.L., Johnson K.P. \& Clayton D.H. (eds) The Chewing Lice: World Checklist and Biological Overview: 1-447. Illinois Natural History Survey Special Publication.

Rafyi A., Alavi A. \& Rak H. 1968. Bird lice in Iran. Journal of the Veterinary faculty of the University of Teheran 25: 107-123.

Rahman W.A. \& Haziqah F. 2015. Ectoparasitic fauna of scavenging chickens (Gallus domesticus) from Penang Island, Peninsular Malaysia. Malaysian Journal of Veterinary Research 6: 33-42.

Rezaei F., Hashemnia M., Chalechale A., Seidi S. \& Gholizadeh M. 2016. Prevalence of ectoparasites in free-range backyard chickens, domestic pigeons (Columba livia domestica) and turkeys in Kermanshah province, west of Iran. Journal of Parasitic Diseases 40: 448-453.

https://doi.org/10.1007/s12639-014-0524-5

Rudolph D. 1983. The water-vapour uptake system of the Phthiraptera. Journal of Insect Physiology 29: $15-25$.

Ryder W.D. 1967. The dispersal of certain species of Mallophaga which infest the domestic fowl, Gallus domesticus. Journal of Applied Ecology 4: 309-323.

Sadiq N.A., Adejinmi J.O., Adedokun O.A., Fashanu S.O., Alimi A.A. \& Sofunmade Y.T. 2003. Ectoparasites and haemoparasites of indigenous chicken (Gallus domesticus) in Ibadan and environs. Tropical Veterinarian 21: 187-191. https://doi.org/10.4314/tv.v21i4.4541

Salam S.T., Mir M.S. \& Khan A.R. 2009. Prevalence and seasonal variation of ectoparasite load in freerange chicken of Kashmir valley. Tropical Animal Health and Production 41: 1371-1376.

https://doi.org/10.1007/s11250-009-9324-9

Sánchez-Montes S., Colunga-Salas P., Álvarez-Castillo L., Guzmán-Cornejo C. \& MontielParra G. 2018. Chewing lice (Insecta: Phthiraptera) associated with vertebrates in Mexico. Zootaxa 4372: 1-109. https://doi.org/10.11646/zootaxa.4372.1.1

Santos A.C.G. dos, Rodrigues A.L., dos Santos S.B., Lima R.C.A. \& Guerra R. de M. S.N. de C. 2011. Phthiraptera (Arthropoda, Insecta) in Gallus gallus from isolated and mixed backyard rearing systems. Revista Brasileira de Parasitologia Veterinaria 20: 17-21.

https://doi.org/10.1590/S1984-29612011000100004

Santos-Prezoto H.H., Silva M.O., Daemon E., D’Agosto M. \& Prezoto F. 2003. Sítios de localização de ectoparasitos em Gallus gallus Linnaeus, 1758. Revista brasileiras de Zoociências Juiz de Fora 5: $129-135$. 
Sayin Ipek D.N. \& Saki C.E. 2009. Diyatbakir ve Yöresinde Tavuklarda Bulunan Bit (Mallophaga) Türleri ve Bunlarin Yayilisi. Dicle Üniversitesi Veteriner Fakültesi Dergisi 2: 64-68.

Saxena A.K. \& Agarwal G.P. 1982. Effect of different temperatures and humidities on the development of the eggs of poultry louse, Lipeurus lawrensis tropicalis (Phthiraptera: Ischnocera). Angewandte Parasitologie 23: 227-230.

Saxena A.K., Kumar S., Gupta N. \& Singh S.K. 2004. Prevalence of phthirapteran ectoparasitic insects on domestic hens of Rampur (U.P.). Journal of Parasitic Diseases 28: 57-60.

Segal D.B., Humphrey J.M., Edwards S.J. \& Kirby M.D. 1968. Parasites of man and domestic animals in Vietnam, Thailand, Laos, and Cambodia: host list and bibliography. Experimental Parasitology 23: 412-464. https://doi.org/10.1016/0014-4894(68)90034-9

Séguy E. 1944. Insectes Ectoparasites (Mallophages, Anoploures, Siphonapteres). In: Chopard (ed.) Fauna de France. Volume 43: 23-407. Paul Lechevalier et fils, Paris.

Serda B. \& Abdi M. 2018. Prevalence of ectoparasites infestation in poultry in Haramaya District, Eastern Hararghe Zone; Oromia Region, Ethiopia. Journal of Veterinary Science and Technology 9: 3.

Shahjehan I.A. \& Iqbal S. 1995. Prevalence of chicken's lice (Mallophaga) in Peshawar and Mansehra (NWFP). Pakistan Veterinary Journal 15: 58-60.

Shanta I.S., Begum N., Anisuzzaman Bari A.S.M. \& Karim M.J. 2006. Prevalence and clinicopathological effects of ectoparasites in backyard poultry. Bangladesh Journal of Veterinary Medicine 4: 19-26. https://doi.org/10.3329/bjvm.v4i1.1520

Sugimoto M. 1930. On some Mallophaga from domestic fowl of Chinese provenience. Journal of the Society of Tropical Agriculture 2: 129-134.

Sugimoto M. 1934. Additional information on the head lice of domestic birds. Taiwan no Chikusan 2: $1-9$.

Suhaila A.H., Sabrina D.L., Nik Ahmad Irwan Izzauddin N.H., Hamdan A. \& Khadijah S. 2015. Study of parasites in commercial free-range chickens in northern Peninsular Malaysia. Malaysian Journal of Veterinary Research 6: 53-64.

Swai E.S., Kessy M., Sanka P., Bwanga S. \& Kaaya J.E. 2010. A survey on ectoparasites and haemoparasites of free-ranging indigenous chickens of Northern Tanzania. Livestock Research for Rural Development 22: [not paginated].

Sychra O., Harmat P. \& Literák I. 2008. Chewing lice (Phthiraptera) on chickens (Gallus gallus) from small backyard flocks in the eastern part of the Czech Republic. Veterinary Parasitology 152: 344-348. https://doi.org/10.1016/j.vetpar.2008.01.001

Tamiru F., Dagmawit A., Askale G., Solomon S., Morka D. \& Waktole T. 2014. Prevalence of ectoparasite infestation in chicken in and around Ambo Town, Ethiopia. Journal of Veterinary Science and Technology 5: 4. https://doi.org/10.4172/2157-7579.1000189

Tendeiro J. 1958. Études sur les Mallophages. Observations sur les Cuclotogaster (Ischnocera, Philopteridae) parasites des Galliformes des genres Francolinus et Pternistis. Junta de Investigações Cientificas do Ultramar. Estudos, Ensaios e Documentos 44: 1-126.

Thamer N.K., Munadil D., Adbulazizz Almeelman S.A. \& Noeri D. 2016. A taxonomical study of lice from some birds at Southern Iraq. Journal of International Academic Research for Multidisciplinary 3: $25-34$.

Thompson R.P. 1968. A survey of ectoparasite infestations on poultry flocks in Nova Scotia and Price Edward Island. Canadian Entomologist 100: 402-407. https://doi.org/10.4039/Ent100402-4 
Thompson R.P. \& Hosking W.F. 1957. A count of Mallophaga on a heavily infested hen. Poultry Science 36: 213-214. https://doi.org/10.3382/ps.0360213

Tolossa Y.H., Shafi Z.D. \& Basu A.K. 2009. Ectoparasites and gastrointestinal helminthes of chickens of three agro-climatic zones in Oromia Region, Ethiopia. Animal Biology 59: 289-297.

https://doi.org/10.1163/157075609X454926

Tolossa Y.H. \& Tafesse H.A. 2013. Occurrence of ectoparasites and gastro-intestinal helminthes infections in Fayoumi chickens (Gallus gallus Fayoumi) in Debre Zeit Agricultural Research Center Poultry Farm, Oromia region, Ethiopia. Journal of Veterinary Medicine and Animal Health 5: 107-112.

Trivedi M.C., Rawat B.S. \& Saxena A.K. 1991. The distribution of lice (Phthiraptera) on poultry (Gallus domesticus). International Journal for Parasitology 21: 247-249.

https://doi.org/10.1016/0020-7519(91)90016-Z

Trivedi M.C., Saxena A.K. \& Rawat B.S. 1992. Incidence of Mallophaga on poultry in Dehradun (India). Angewandte Parasitologie 33: 69-78.

Usman M., Fabiyi J.P., Mohammed A.A., Mera U.M., Mahmuda A., Alayande M.O., Lawal M.D. \& Danmaigoro A. 2012. Ectoparasites and haemoparasites of chicken in Sokoto, northwestern Nigeria. Scientific Journal of Zoology 1: 74-78.

Vazirianzadeh B., Rahdar M \& Molaee S.M. 2007. Mallophaga of domestic birds of Ahwaz, Iran. Journal of Experimental Zoology, India 10: 75-77.

Wang F.F., Wang M., Xu F.R., Liang D.M. \& Pan B.L. 2010. Survey of prevalence and control of ectoparasites in caged poultry in China. Veterinary Record 167:934-937.https://doi.org/10.1136/vr.c6212

Wang N., Kimball R.T., Braun E.L., Liang B. \& Zhang Z. 2013. Assessing phylogenetic relationships among Galliformes: a multigene phylogeny with expanded taxon sampling in Phasianidae. PLoS One 8 (5): e64312. https://doi.org/10.1371/journal.pone.0064312

Yevstafieva V.A. 2015. Chewing lice (order Mallophaga, suborders Amblycera and Ichnocera [sic]) fauna of domestic chicken (Gallus gallus domesticus) in Ukraine. Vestnik Zoologii 49: 393-400. https://doi.org/10.1515/vzoo-2015-0044

Zaria L.T., Sinha P.K., Natiti L.S. \& Nawathe D.R. 1996. Incidence of ectoparasites of domestic fowl in an arid zone of Nigeria. Nigerian Journal of Animal Production 23: 91-93.

Zeryehun T. \& Yohannes Y. 2015. Ectoparasite infestation of free scavenging chickens reared under traditional backyard production system in Wolayita Zone, southern Ethiopia. Ethiopian Veterinary Journal 19: 55-66. https://doi.org/10.4314/evj.v19i2.2

Złotorzycka J. 1966. Systematische Bemerkungen über der Gattung Reticulipeurus Kéler mit Beschreibung von R. tetraonis minor ssp. n. (Mallophaga, Lipeuridae). Polskie Pismo Entomologiczne 36: 111115.

Manuscript received: 12 November 2019

Manuscript accepted: 16 April 2020

Published on: 14 July 2020

Topic editor: Nesrine Akkari

Desk editor: Kristiaan Hoedemakers 
Printed versions of all papers are also deposited in the libraries of the institutes that are members of the EJT consortium: Muséum national d'histoire naturelle, Paris, France; Meise Botanic Garden, Belgium; Royal Museum for Central Africa, Tervuren, Belgium; Royal Belgian Institute of Natural Sciences, Brussels, Belgium; Natural History Museum of Denmark, Copenhagen, Denmark; Naturalis Biodiversity Center, Leiden, the Netherlands; Museo Nacional de Ciencias Naturales-CSIC, Madrid, Spain; Real Jardín Botánico de Madrid CSIC, Spain; Zoological Research Museum Alexander Koenig, Bonn, Germany; National Museum, Prague, Czech Republic. 